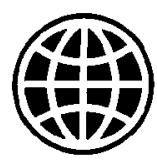

WORLD BANK

Work in progress

for public discussion
WDP428

January 2002

\title{
Managing the Real and Fiscal Effects of Banking Crises
}

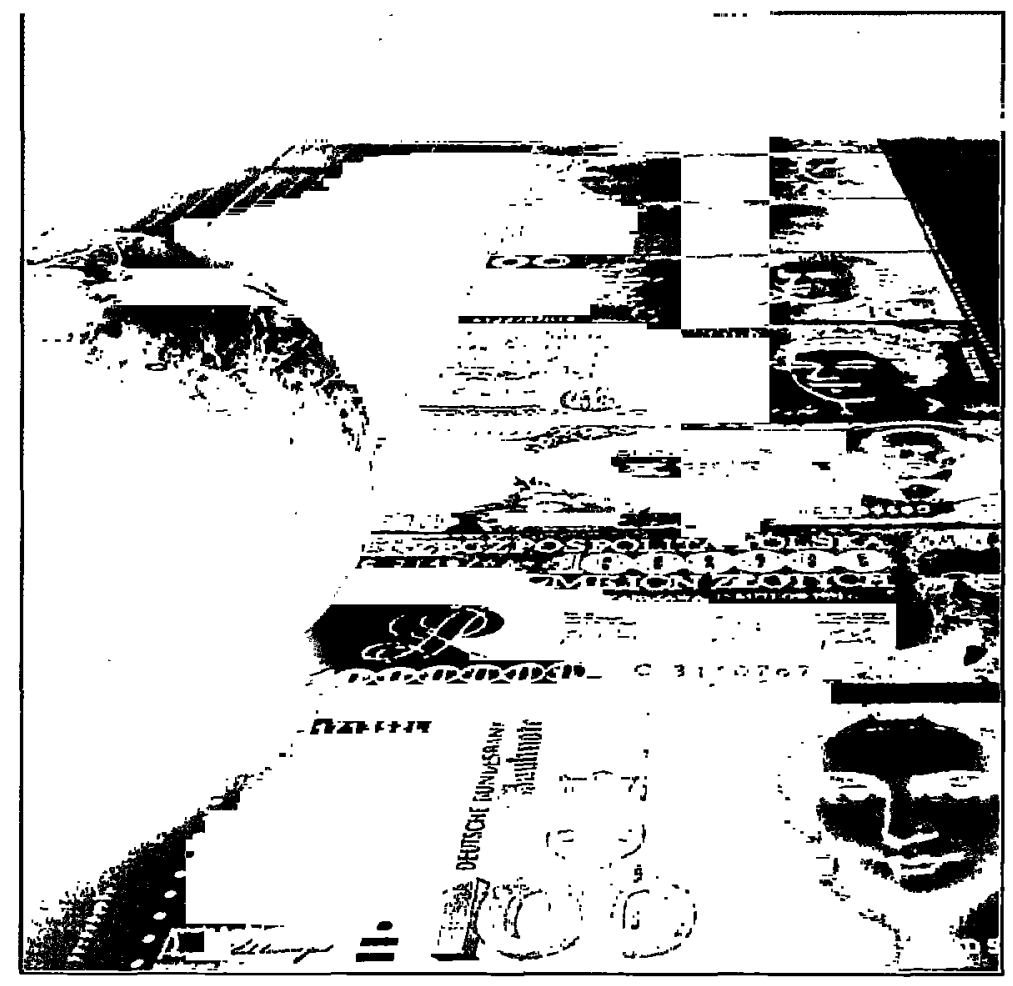

Edited by

Daniela Klingebiel

Luc Laeven 


\section{Recent World Bank Discussion Papers}

No. 351 From Universal Food Subsidies to a Self-Targeted Program: A Case Study in Tunisian Reform. Laura Tuck and Kathy Lindert

No. 352 China's Urban Transport Development Strategy: Proceedings of a Symposium in Beijing, November 8-10, 1995. Edited by Stephen Stares and Liu Zhi

No. 353 Telecommunications Policies for Sub-Saharan Africa. Mohammad A. Mustafa, Bruce Laidlaw, and Mark Brand

No. 354 Saving across the World: Puzzles and Policies. Klaus Schmidt-Hebbel and Luis Servén

No. 355 Agriculture and German Reunification. Ulrich E. Koester and Karen M. Brooks

No. 356 Evaluating Health Projects: Lessons from the Literature. Susan Stout, Alison Evans, Janet Nassim, and Laura Raney, with substantial contributions from Rudolpho Bulatao, Varun Gauri, and Timothy Johnston

No. 357 Innovations and Risk Taking: The Engine of Reform in Local Government in Latin America and the Caribbean. Tim Campbell

No. 358 China's Non-Bank Financial Institutions:Trust and Investment Companies. Anjali Kumar, Nicholas Lardy, William Albrecht, Terry Chuppe, Susan Selwyn, Paula Perttunen, and Tao Zhang

No. 359 The Demand for Oil Products in Developing Countries. Dermot Gately and Shane S. Streifel

No. 360 Preventing Banking Sector Distress and Crises in Latin America: Proceedings of a Conference held in Washington, D.C., April 15-16, 1996. Edited by Suman K. Bery and Valeriano F. Garcia

No. 361 China: Power Sector Regulation in a Socialist Market Economy. Edited by Shao Shiwei, Lu Zhengyong, Norreddine Berrah, Bernard Tenenbaum, and Zhao Jianping

No. 362 The Regulation of Non-Bank Financial Institutions: The United States, the European Union, and Other Countries. Edited by Anjali Kumar with contributions by Terry Chuppe and Paula Perttunen

No. 363 Fostering Sustainable Development: The Sector Investment Program. Nwanze Okidegbe

No. 364 Intensified Systems of Farming in the Tropics and Subtropics. J.A. Nicholas Wallis

No. 365 Innovations in Health Care Financing: Proceedings of a World Bank Conference, March 10-11, 1997. Edited by George J. Schieber

No. 366 Poverty Reduction and Human Development in the Caribbean: A Cross-Country Study. Judy L. Baker

No. 367 Easing Barriers to Movement of Plant Varieties for Agricultural Development. Edited by David Gisselquist and Jitendra Srivastava

No. 368 Sri Lanka's Tea Industry: Succeeding in the Global Market. Ridwan Ali, Yusuf A. Choudhry, and Douglas W. Lister

No. 369 A Commercial Bank's Microfinance Program: The Case of Hatton National Bank in Sri Lanka. Joselito S. Gallardo, Bikki K. Randhawa, and Orlando J. Sacay

No. 370 Sri Lanka's Rubber Industry: Succeeding in the Global Market. Ridwan Ali, Yusuf A. Choudhry, and Douglas W. Lister

No. 371 Land Reform in Ukraine: The First Five Years. Csaba Csaki and Zvi Lerman

No. 373 A Poverty Profile of Cambodia. Nicholas Prescott and Menno Pradhan

No. 374 Macroeconomic Reform in China: Laying the Foundation for a Socialist Economy. Jiwei Lou

No. 375 Design of Social Funds: Participation, Demand Orientation, and Local Organizational Capacity. Deepa Narayan and Katrinka Ebbe

No. 376 Poverty, Social Services, and Safety Nets in Vietnam. Nicholas Prescott

No. 377 Mobilizing Domestic Capital Markets for Infrastructure Financing: International Experience and Lessons for China. Anjali Kumar, R. David Gray, Mangesh Hoskote, Stephan von Klaudy, and Jeff Ruster

No. 378 Trends in Financing Regional Expenditures in Transition Economies: The Case of Lkraine. Nina Bubnova and Lucan Way

No. 379 Empowering Small Enterprises in Zimbabwe. Kapil Kapoor, Doris Mugwara, and Isaac Chidavaenzi

No. 380 India's Public Distribution System: A National and International Perspective. R. Radhakrishna and K. Subbarao, with S. Indrakant and C. Ravi

No. 381 Market-Based Instruments for Environmental Policymaking in Latin America and the Caribbean: Lessons from Eleven Countries. Richard M. Huber, Jack Ruitenbeek, and Ronaldo Serôa da Motta.

No. 382 Public Expenditure Reform under Adjustment Lending: Lessons from World Bank Experiences. Jeff Huther, Sandra Roberts, and Anwar Shah

No. 383 Competitiveness and Employment: A Framework for Rural Development in Poland. Garry Christensen and Richard Lacroix 
WORLD BANK DISCUSSION PAPER NO. 428

\section{Managing the Real and Fiscal Effects of Banking Crises}

Edited by

Daniela Klingebiel

Luc Laeven

The World Bank

Washington, D.C. 
Copyright $\odot 2002$

The International Bank for Reconstruction

and Development/THE WORLD BANK

1818 H Street, N.W.

Washington, D.C. 20433, U.S.A.

All rights reserved

Manufactured in the United States of America

First printing January 2002

1234040302

Discussion Papers present results of country analysis or research that are circulated to encourage discussion and comment within the development community. The typescript of this paper therefore has not been prepared in accordance with the procedures appropriate to formal printed texts, and the World Bank accepts no responsibility for errors. Some sources cited in this paper may be informal documents that are not readily available.

The findings, interpretations, and conclusions expressed in this paper are entirely those of the author(s) and should not be attributed in any manner to the World Bank, to its affiliated organizations, or to members of its Board of Executive Directors or the countries they represent. The World Bank does not guarantee the accuracy of the data included in this publication and accepts no responsibility for any consequence of their use. The boundaries, colors, denominations, and other information shown on any map in this volume do not imply on the part of the World Bank Group any judgment on the legal status of any territory or the endorsement or acceptance of such boundaries.

The material in this publication is copyrighted. The World Bank encourages dissemination of its work and will normally grant permission promptly.

Permission to photocopy items for internal or personal use, for the internal or personal use of specific clients, or for educational classroom use, is granted by the World Bank, provided that the appropriate fee is paid directly to Copyright Clearance Center, Inc., 222 Rosewood Drive, Danvers, MA 01923, U.S.A., telephone 978-750-8400, fax 978-750-4470. Please contact the Copyright Clearance Center before photocopying items.

For permission to reprint individual articles or chapters, please fax your request with complete information to the Republication Department, Copyright Clearance Center, fax 978-750-4470.

All other queries on rights and licenses should be addressed to the World Bank at the address above or faxed to $202-522-2422$.

ISBN: 0-8213-5056-0

ISSN: 0259-210X

Daniela Klingebiel is a Senior Financial Economist at the World Bank. Luc Laeven is a Financial Economist at the World Bank

Cover photo: Bank Polanska Kasa Opieki SA

Library of Congress Cataloging-in-Publication Data has been applied for. 
iii

Contents

Foreword

Abstract

$v$

vii

Financial Restructuring in Banking and Corporate Sector Crises:

Which Policies to Pursue?

Stijn Claessens, Daniela Klingebiel, and Luc Laeven

1

Controlling the Fiscal Costs of Banking Crises

Patrick Honohan and Daniela Klingebiel

15

Episodes of Systemic and Borderline Banking Crises

Gerard Capri and Daniela Klingebiel

31 



\section{Foreword}

I

$n$ recent decades many countries have experienced systemic banking crises requiring

major restructurings of their financial systems. These restructurings have often had high fiscal costs, with budget outlays sometimes exceeding 50 percent of GDP. The recent East Asian crisis spurred a debate on policies needed to restore financial stability and avert and mitigate future financial crises. Managing and resolving a financial crisis is a complex undertaking-and one that raises important questions about government's role. To advance the dialogue on these issues, World Bank Group staff have prepared a number of papers, three of which are presented in this volume.
These papers are not intended to reflect the Bank Group's policies, but rather to stimulate debate in and solicit views from the development community at large.

While the papers in this volume were motivated by events that took place during the East Asian crisis, they also draw on experiences from other regions. Although many questions remain to be answered, this volume contributes to the literature by providing an overview of the lessons learned from past government policies aimed at managing and resolving financial crises. The volume will be of particular interest to policymakers involved with financial and corporate sector reform.

Cesare Calari

Vice President, Financial Sector The World Bank 



\section{Abstract}

$\mathrm{T}$

his volume provides two recent analyses, spurred by the recent East Asian crisis, of government responses to financial distress.

It also presents a comprehensive database on systemic and borderline banking crises.

In the first chapter Stijn Claessens, Daniela Klingebiel, and Luc Laeven review the tradeoffs involved in public policies for systemic financial and corporate sector restructuring. The authors find that consistent policies are crucial for success, though such consistency is often missing. This consistency covers many dimensions and entails, among other things, ensuring that there are sufficient resources for absorbing losses and that private agents face appropriate incentives for restructuring. The authors also find that sustainable restructuring requires deep structural reforms, which typically require that political economy factors be addressed upfront.
In the second chapter Patrick Honohan and Daniela Klingebiel use cross-country evidence to determine whether specific crisis containment and resolution policies systematically influence the fiscal costs of resolving a crisis. The authors find that accommodating policiessuch as blanket deposit guarantees, openended liquidity support, repeated (and so partial) recapitalizations, debtor bailouts, and regulatory forbearance - significantly increase fiscal costs.

The third chapter, by Gerard Caprio and Daniela Klingebiel, is a comprehensive database on 113 systemic banking crises that have occurred in 93 countries since the late $1970 \mathrm{~s}$. The database also includes information on 50 borderline (nonsystemic) banking crises in 44 countries during the same period. 



\title{
Financial Restructuring in Banking and Corporate Sector Crises: Which Policies to Pursue?
}

\author{
Stijn Claessens, Daniela Klingebiel, and Luc Laeven
}

Stijn Claessens is professor of international finance at the University of Amsterdam and research fellow at the Centre for Economic Policy Research. Daniela Klingebiel is senior financial economist in the Financial Sector Strategy and Policy Department at the World Bank. Luc Laeven is financial economist in the Financial Sector Strategy and Policy Department at the World Bank. An earlier version of this chapter was presented at the National Bureau for Economic Research conference on Management of Currency Crises, held in Monterey, California, on 28-31 March 2001. The authors are grateful to Gerard Caprio, Jeffrey Frankel, Peter Kenen, Tom Rose, and other conference participants for helpful comments, and to Ying Lin for help with the data.
$\mathrm{R}$ esolving a systemic banking and corporate crisis involves many policy choices ranging from macroeconomic (including monetary and fiscal policy) to microeconomic (including capital adequacy rules and corporate governance requirements), with reforms varying in depth. ${ }^{1}$ These choices involve tradeoffs that influence the amount of government resources needed to resolve the crisis, the speed of recovery, and the recovery's sustainability. Despite considerable analysis, these tradeoffs are not well known-an oversight that occasionally leads to conflicting policy advice and larger than necessary economic costs. Even less is known about the political economy factors that make governments choose certain policies.

This chapter reviews knowledge about the tradeoffs involved in policies related to systemic financial and corporate restructuring. It finds that a consistent framework is the key factor for successful restructuring - and one that is often missing. Consistency is needed in many areas and involves, among other elements, ensuring that there are sufficient resources for absorbing losses and that private agents face appropriate incentives for restructuring. Moreover, sustainable restructuring requires deep structural reforms, which often require addressing political economy factors upfront.

The next section provides an overview of banking and corporate crises. After that the chapter reviews the literature on such crises. The final section concludes.

1 In this chapter systemic is used to refer to a crisis that is large relative to a national economy, not necessarily large relative to the global economy or one that has other global spillovers.

\section{Characteristics of banking and corporate crises}

A systemic banking and corporate crisis is a situation where an economy faces large-scale financial and corporate distress within a short period. ${ }^{2}$ Recent examples include the crisis in Nordic countries in the early 1990 s, in Mexico in 1994-95, in East Asian countries after 1997, and in transition economies in the 1990s (though for transition economies, financial distress and structural problems had been longer-term phenomena). Banking and corporate crises appear to have become more common since the early 1980s: Caprio and Klingebiel (in this volume) identify 93 countries that experienced a systemic financial crisis during the 1980s or 1990s (figure 1). It also appears that crises became deeper in the 1990s relative to earlier periods (Bordo and others 2001).

In a systemic crisis, partly as a result of a general economic slowdown and large shocks to foreign exchange and interest rates, corporate and financial sectors experience a large number of defaults and difficulties repaying contracts on time. As a result nonperforming loans increase sharply. This situation is often accompanied by depressed asset prices (such as equity and real estate prices) on the heels of run-ups before the crisis, sharp increases in real interest rates, and a slowdown or

2 We do not try to identify the exact causes of systemic distress or determine whether currency crises are caused by systemic financial distress in banks and corporations or vice versa. For such analysis, see Edwards and Frankel (forthcoming). 
Figure 1
Frequency of systemic banking crises, 1980-98
Number of crisis episodes, by year crisis started

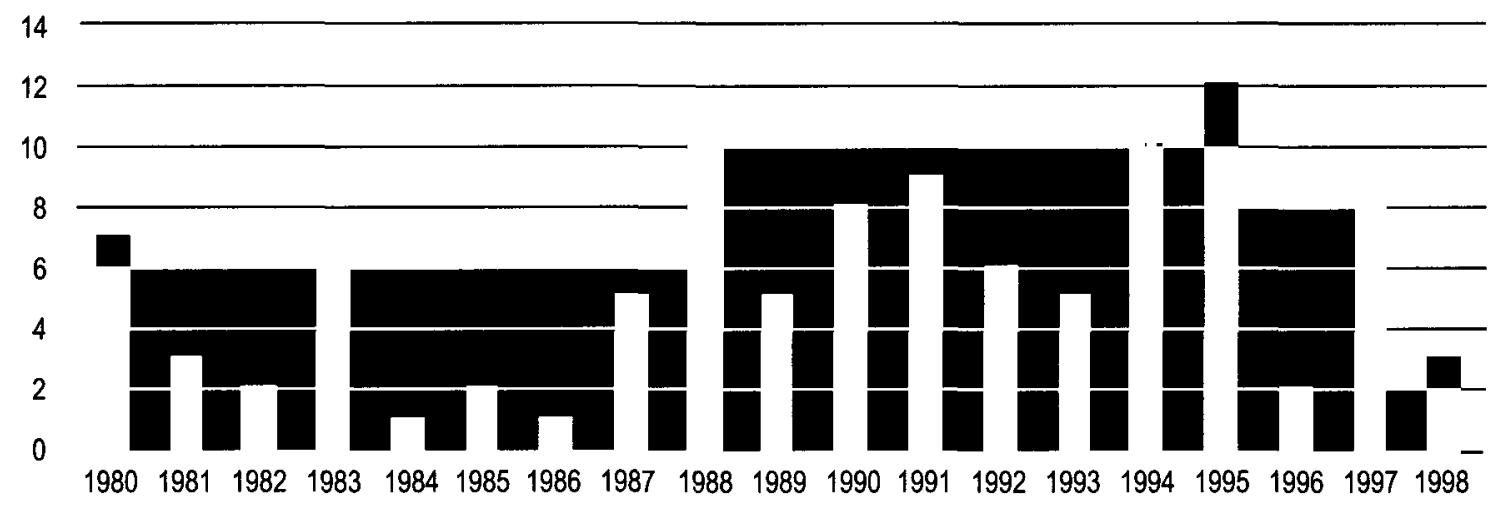

Note: The sample contains 93 crisis countries; some countries experienced more than one crisis.

Source: Caprio and Klingebiel (in this volume); authors calculations.

reversal in capital flows (table 1). In countries with longer-term financial distress and other large-scale structural problems-such as several transition economies-a systemic crisis may not be accompanied by such changes in asset prices and capital flows, partly because run-ups in prices and capital flows may not have occurred.

Developments in crisis countries highlight the complicated coordination problems that arise between corporations, between the corporate and financial sectors, between the government and the rest of the economy, and with respect to domestic and foreign investors. In a systemic crisis the fate of an individual corporation and the best course of action for its owners and managers will depend on the actions of many other corporations and financial institutions as well as the general economic outlook. The financial and corporate sectors, always closely intertwined, both need restructuring in a systemic crisis, and the actions taken affect their liquidity and solvency. The government must set the rules of the game and be a prominent actor in restructuring. And investors, domestic and foreign, will await the actions of owners, the government, labor, and others-often implying a shortage of foreign and domestic capital when it is most needed.

A crisis and its coordination problems are typically aggravated by institutional weaknesses, many of which likely contributed to the crisis in the first place. Bankruptcy and restructuring frameworks are often deficient. Disclosure and accounting rules may be weak for financial institutions and corporations. Equity and creditor rights may be poorly defined. And the judiciary is often inefficient. There is usually also a shortage of qualified managers in the corporate and financial sectors, as well as a lack of qualified domestic restructuring and insolvency specialists-partly because there may be no history of corporate and financial sector restructuring. The government itself may face credibility problems because it may have been partly to blame for the crisis, and in general faces many time consistency problems - such as how to avoid large bailouts while also restarting the economy.

These complicated coordination problems suggest that systemic crises are difficult to resolve. Many observers have tried to develop best practices for resolving such crises. We next review that literature.

\section{Literature on banking and corporate crises}

Governments have used many approaches to try to resolve systemic bank and corporate distress.

Resolving systemic financial distress is not easy, and opinions differ widely on what constitutes best practice. Many different and seemingly contradictory policy recommendations have been made to limit the fiscal costs of crises and speed recovery. Empirical research supporting particular 
Table 1

Patterns of systemic banking crises, various countries

Percent

\begin{tabular}{|c|c|c|c|c|c|c|c|}
\hline Country & $\begin{array}{l}\text { Crisis } \\
\text { year }\end{array}$ & $\begin{array}{l}\text { Fiscal cost } \\
\text { (share of GDP) }\end{array}$ & $\begin{array}{l}\text { Peak } \\
\text { nonperforming } \\
\text { loans (share of } \\
\text { total loans) }\end{array}$ & $\begin{array}{l}\text { Real change } \\
\text { in GDP }\end{array}$ & $\begin{array}{l}\text { Change in } \\
\text { exchange rate }\end{array}$ & $\begin{array}{l}\text { Peak real } \\
\text { interest rate }\end{array}$ & $\begin{array}{l}\text { Decline in real } \\
\text { asset prices }\end{array}$ \\
\hline Finland & 1992 & 11.0 & 13 & -4.6 & -5.5 & 14.3 & -34.6 \\
\hline Indonesia & 1998 & 50.0 & $65-75$ & -15.4 & -57.5 & 3.3 & -78.5 \\
\hline Korea, Rep. of & 1998 & 37.0 & $30-40$ & -10.6 & -28.8 & 21.6 & -45.9 \\
\hline Malaysia & 1998 & 16.4 & $25-35$ & -12.7 & -13.9 & 5.3 & -79.9 \\
\hline Mexico & 1995 & 19.3 & 30 & -6.2 & -39.8 & 24.7 & -53.3 \\
\hline Philippines & 1998 & 0.5 & 20 & -0.8 & -13.0 & 6.3 & -67.2 \\
\hline Sweden & 1991 & 4.0 & 18 & -3.3 & 1.0 & 79.2 & -6.8 \\
\hline Thailand & 1998 & 32.8 & 33 & -5.4 & -13.7 & 17.2 & -77.4 \\
\hline \multicolumn{8}{|c|}{$\begin{array}{l}\text { Source: Crisis year is the peak crisis year, from Caprio and Klingebiel (in this volume). Fiscal cost is from Honohan and Klingebiel (2000). Peak } \\
\text { nonperforming loans is from Caprio and Klingebiel (in this volume) for Indonesia, Republic of Korea, Malaysia, the Philippines, and Thailand; Claessens, } \\
\text { Djankov, and Klingebiel (2001) for Finland and Sweden; and Krueger and Tomell (1999) for Mexico. Real change in GDP is the percentage change in } \\
\text { real fourth-quarter GDP in the crisis year relative to real fourth-quarter GDP the year before. Consumer price index inflation is used to calculate real GDP } \\
\text { growth, and growth is in terms of local currency. GDP data are from the International Monetary Fund s International Financial Statistics. The inflation rate } \\
\text { is the percentage change in the consumer price index during the crisis year and is from International Financial Statistics. Change in exchange rate is the } \\
\text { percentage change in the exchange rate relative to the U.S. dollar during the first quarter of the crisis year. An increase in the exchange rate indicates } \\
\text { appreciation. Exchange rate data are from International Financial Statistics. Peak real interest rate is the peak real money market rate during the crisis } \\
\text { year. For the Philippines the real discount rate is reported instead of the money market rate due to data unavailability. Interest rate data are from } \\
\text { International Financial Statistics. Decline in real asset prices is the lar gest monthly drop in the stock market index during the crisis year relative to the } \\
\text { stock market index in January of the year before. The return is in local currency and corrected for inflation. Datastream global market indexes were used for } \\
\text { Finland, Mexico, and Sweden; Standard and Poor } s \text { and International Finance Corporation global market indexes were used for the other countries. }\end{array}$} \\
\hline
\end{tabular}

views remains limited, and most research is limited to individual cases.

Sheng (1996) was the first attempt to distill lessons from several banking crises. Caprio and Klingebiel (1996) expanded on those lessons using additional crises. The main lesson from both efforts is that managing a financial crisis is much different in industrial countries than in emerging markets because emerging markets have weaker institutions, crises are often larger, and other initial circumstances differ. As a result best practices from industrial countries do not easily transfer to developing countries. Another key lesson is that there are many tradeoffs between various policies.

In reviewing the literature on financial restructuring, especially in emerging markets, it is useful to differentiate between three phases of systemic restructuring. During the first phase, which can be called the containment phase, the financial crisis is still unfolding. During this phase governments tend to implement policies aimed at restoring public confidence to minimize the repercussions on the real sector of the loss of confidence by depositors and other investors in the financial system. The second phase involves the actual financial, and to a lesser extent operational, restructuring of financial institutions and corporations. The third phase involves structural reforms, including changes in laws and regulations, privatization of any nationalized financial institutions and corporations, and so on. Here we discuss the containment phase, the restructuring of financial institutions, and the restructuring of corporations.

\section{Containment phase}

Policymakers often fail to respond effectively to evidence of an impending banking crisis, hoping that banks and corporations will grow out of their problems. ${ }^{3}$ But intervening early with a comprehensive and credible plan can avoid a systemic crisis, minimize adverse effects, and limit

3 There are many political economy reasons why policymakers may not wish to act-thereby giving rise to a crisis-but we do not discuss them here (for such analysis, see Haggard 2001). 
overall losses (Sheng 1996). Early intervention appears to be especially important in stopping the flow of financing to loss-making financial institutions and corporations and in limiting moral hazard in financial institutions and corporations gambling for survival.

Experience also suggests that intervention and closing of weak financial institutions need to be properly managed. Uncertainty among depositors needs to be limited; otherwise the government may have to try to resolve a loss of confidence by providing an unlimited guarantee on the liabilities of banks and other financial institutions. But in practice, ad hoc closures are more the norm and often add to uncertainty, triggering a systemic crisis. For example, in late 1997 the closing of 16 banks in Indonesia triggered a depositor run because depositors were aware that some politically connected banks known to be insolvent were kept open (Lindgren and others 2000). Similarly, the suspension of finance companies in Thailand in 1997 increased uncertainty among depositors as well as borrowers.

Reviewing several cases, Baer and Klingebiel (1995) suggest that, to avoid uncertainty among depositors and limit their incentives to run, policymakers need to deal simultaneously with all insolvent and marginally solvent institutions. Intermittent regulatory intervention makes depositors more nervous and undermines regulatory credibility-especially if regulators had previously argued that the institutions involved were solvent. ${ }^{4}$ Moreover, in emerging markets regulations are often weak, supervision is limited, and data on financial solvency are poor, so intervention tools need to be fairly simple.

For example, a rehabilitation program for undercapitalized financial institutions-which involves institutions indicating how they plan to

4 Baer and Klingebiel also point out that a comprehensive approach places less demand on supervisory resources. Under a piecemeal approach, insolvent and marginally solvent institutions continue to exist while other insolvent institutions are being closed or restructured. Marginally solvent institutions are subject to moral hazard and fraud while being unable and unwilling to raise additional capital. Especially in an environment with weak supervision, comprehensive approaches are thus more necessary. meet capital adequacy requirements in the futurerequires careful government oversight and good financial statements. But such features are often missing in developing countries. Instead of relying on rehabilitation that requires good oversight and data, regulators could apply a 100 percent (marginal) reserve requirement on deposit inflows and other new liabilities, limiting weak banks' ability to reallocate resources in a detrimental way.

There are two schools of thoughts on whether to use liquidity support and unlimited guarantees during the containment phase. ${ }^{5}$ Some argue that crisis conditions make it almost impossible to distinguish between solvent and insolvent institutions, leaving the authorities with little choice but to extend liquidity support. Moreover, it is argued that an unlimited deposit guarantee preserves the payments system and helps stabilize institutions' financial claims while restructuring is being organized and carried out (Lindgren and others 2000).

Others argue that open-ended liquidity support provides more time for insolvent institutions to gamble (unsuccessfully) on resurrection, facilitates continued financing of loss-making borrowers, and allows owners and managers to engage in looting. Supporters of this view also argue that a government guarantee on financial institutions' liabilities reduces large creditors' incentives to monitor financial institutions, allowing bank managers and shareholders to continue gambling on their insolvent banks and increasing fiscal costs. They further point out that extensive guarantees limit government maneuverability in allocating losses, often with the end result that government incurs most of the costs of the systemic crisis (Sheng 1996).

In practice, there is a tradeoff between restoring confidence and containing fiscal costs. Evidence on these tradeoffs comes from Honohan and Klingebiel (in this volume), who show that much of the variation in the fiscal costs of 40 crises in industrial and developing economies in 1980-97 can be explained by government approaches to resolving liquidity crises. The authors find that governments

5 A third school argues that the granting of government guarantees is the outcome of political economy circumstances, and so is often a foregone conclusion (see Dooley and Verma forthcoming). 
that provided open-ended liquidity support and blanket deposit guarantees incurred much higher costs in resolving financial crises. They also find that these costs are higher in countries with weak institutions.

Most important, Honohan and Klingebiel find no obvious tradeoff between fiscal costs and subsequent economic growth (or overall output losses). Countries that used policies such as liquidity support, blanket guarantees, and regulatory forbearance did not recover faster. Rather, liquidity support appears to make recovery from a crisis longer and output losses larger-a finding confirmed by Bordo and others (2001). Thus it appears that the two most important policies during the containment phase are to limit liquidity support and not extend guarantees. And where institutions are weak, governments may need to use simple methods in dealing with weak banks and a loss of confidence to avoid higher fiscal contingencies and costs.

\section{Restructuring financial institutions}

Once financial markets have been stabilized, the second phase of systemic restructuring involves restructuring weak financial institutions and corporations. Restructuring is complex because policymakers need to take into account many issues. Financial and corporate restructuring will depend on the speed at which macroeconomic stability can be achieved because that determines the viability of corporations, banks, and other financial institutions, and more generally the reduction in overall uncertainty. But macroeconomic stability often requires progress on financial and corporate restructuring, and so cannot be viewed independently of the restructuring process (see Burnside, Eichenbaum, and Rebelo forthcoming and Park and Lee forthcoming).

Restructuring refers to several related processes: recognizing and allocating financial losses, restructuring the financial claims of financial institutions and corporations, and restructuring the operations of financial institutions and corporations. Recognition involves the allocation of losses and associated redistribution of wealth and control. Losses-that is, differences between the market value of assets and the nominal value of liabilities held by financial institutions and corporations - can be allocated to shareholders (through dilution), to depositors and creditors (by reducing the present value of their claims), to employees (through reduced wages) and suppliers, and to the government or the public (through higher taxes, lower spending, or inflation). Here we discuss the restructuring of financial institutions; the next section discusses the restructuring of corporations.

To minimize moral hazard and strengthen financial discipline, governments can allocate losses not only to shareholders but also to creditors and large depositors who should have been monitoring the banks. Governments often assume all losses through their guarantees. But there are exceptions to the model of governments guaranteeing all liabilities in an effort to restore confidence. Baer and Klingebiel (1995) show that in some crisesnotably in the United States (1933), Japan (1946), Argentina (1980-82), and Estonia (1992)governments have imposed losses on depositors with little or no adverse macroeconomic consequences or flight to currency. In these cases economic recovery was rapid and financial intermediation, including household deposits, was soon restored. Thus allocating losses to creditors or depositors will not necessarily lead to runs on banks or end in contraction of aggregate money, credit, and output. In a related vein, Caprio and Klingebiel's (1996) review of country cases indicates that financial discipline is further strengthened when bank management-often part of the problem-is changed and banks are operationally restructured.

Besides loss allocation, financial and corporate restructuring crucially depend on the incentives under which banks and corporations operate. Successful corporate debt workouts require proper incentives for banks and borrowers to come to the negotiating table (Dado and Klingebiel 2000). The incentive framework for banks includes accounting, classification, and provisioning rules - that is, financial institutions need to be asked to realistically mark their assets to market. The framework also includes laws and prudential regulations. Regulators should ensure that undercapitalized financial institutions are properly disciplined and closed. The insolvency system should enable financial institutions to enforce their claims on corporations, allow for speedy financial restructuring of viable corporations, and provide for the efficient liquidation of enterprises that cannot be rehabilitated. Proper incentives also mean limited ownership links between banks and corporations 
(since otherwise the same party could end up being both debtor and creditor).

Adequately capitalized financial institutions are a key component of a proper incentive framework, because financial institutions need to have sufficient loss absorption capacity to engage in sustainable corporate restructuring. In a systemic crisis, capital will often have to come from the government through recapitalization. But general experiencesupported by recent events in East Asia - suggests that recapitalization of financial institutions needs to be structured and managed to limit moral hazard. In their analysis of 40 bank crises, Honohan and Klingebiel (in this volume) find that repeated, incomplete recapitalizations tend to increase the fiscal costs of resolving a crisis. One possible explanation is that marginally capitalized banks tend to engage in cosmetic corporate restructuring such as maturity extensions or interest rate reductions on loans to nonviable corporationsrather than writing off debts.

Besides adequate capitalization, preferably by private shareholders, banks' incentives to undertake corporate restructuring can be strengthened by linking government financing to the restructuring. For example, a capital support scheme in which additional fiscal resources are linked to corporate restructuring through loss sharing arrangements can induce banks to conduct deeper restructuring. Regardless, especially in weak institutional settings, limits on the actions of marginally capitalized banks will typically be necessary.

In principle, governments should only capitalize or strengthen the capital base of financial institutions with charter and franchise value. But apart from political economy problems, it is often difficult for governments to distinguish good banks from bad. Risk sharing mechanisms with the private sector, such as cofinancing arrangements with government equity infusion (in the form of preferred shares) when the private sector provides capital, can help identify better banks. This setup still requires decent institutions to avoid misuse. Especially in a weak institutional environment with limited private capital, governments may want to rely more on hard budget constraints on weak banks (such as a 100 percent marginal reserve requirement on new deposits) to prevent a large leakage of fiscal resources, including through excessive guarantees on financial institutions' liabilities. And good banks may need to be actively coerced to receive support, because they may resist government interference. But without some support, good banks may not be able to provide financial intermediation to corporations, aggravating the crisis.

\section{Restructuring corporations}

Providing the right incentives. The nature of a systemic crisis, and the already close links between the solvency and performance of the corporate and financial sectors in normal times, make it clear that bank restructuring needs to be complemented by corporate restructuring. To start corporate restructuring, corporations should quickly be triaged into operationally viable and not financially distressed corporations, operationally viable but financially distressed corporations, and financially and operationally unviable corporations. In a normal restructuring of an individual case of financial distress, private agents will make these decisions and start the operational and financial restructuring. ${ }^{6}$ But in a systemic crisis case-by-case restructuring is difficult because the incentives under which agents operate are likely not conducive, private capital is typically limited, and coordination problems are large. ${ }^{7}$

Nevertheless, the starting point is providing proper incentives for private agents to allow and encourage market-based, sustainable corporate restructuring. Given that the crisis was likely partly induced by weaknesses in the environment in which the corporate sector operated, the first step for government has to be creating an enabling environment. Depending on country circumstances, this can imply undertaking corporate governance reforms, improving bankruptcy and other restructuring frameworks, making the judicial system more efficient, liberalizing entry by foreign

6 Financial restructuring for corporations can take many forms: loan reschedulings (extensions of maturities), lower interest rates, debt-for-equity swaps, debt forgiveness, indexing interest payments to earnings, and so on. Operational restructuring, an ongoing process, includes improvements in efficiency and management, reductions in staff and wages, asset sales (such as a reduction in subsidiaries), enhanced marketing efforts, and the like, with the expectation of increased profitability and cash flow.

7 For other papers on systemic corporate restructuring, including specific case studies, see Claessens, Djankov, and Mody (2001). 
investors, changing the competitive framework for the real sector, or introducing other supportive structural measures. In general, the political economy of reform suggests that a crisis can often be a time to get difficult structural reforms accepted or at least initiated (Haggard 2001).

Most crisis countries reform the incentives for restructuring, though the strengths and depth of the reforms differ (see Claessens, Djankov, and Klingebiel 2001; Dado and Klingebiel 2000; Stone 2000a, b; and World Bank 2000 for different groups of crisis countries). For example, Indonesia adopted a new bankruptcy system to replace its pre-World War II Dutch code in August 1998, 12 months after its crisis started. Similarly, Thailand's Senate approved the Act for the Establishment of and Procedure for Bankruptcy Court, intended to increase the efficiency of judicial procedures in bankruptcy cases, in February 1999, 19 months after its crisis began. But despite the act's adoption, bankruptcies in Thailand remain infrequent and fraught with difficulties (Foley 2000).

Beyond fixing the environment, it can be necessary to provide extra incentives for private agents to engage in (quick) corporate restructuring. These incentives can involve tax, accounting, and other measures. Banks, for example, may be given more tax relief for provisioning or restructuring loans. Corporations may be given more favorable accounting relief for recognizing foreign exchange losses. In the wake of its crisis, the Republic of Korea adopted more favorable tax rules for corporate restructuring, though they ended up being misused through cosmetic rather than real restructuring. Some countries have offered guarantees on exchange rate behavior, such as Indonesia's INDRA scheme and Mexico's FICORCA scheme; see Stone (2000a). The efficiency of such measures should be evaluated from various perspectives, taking into account their benefits for restructuring and public finance as well as their possible redistributive effects. But while such measures may speed recovery, they often do not contribute to fundamental reforms. In any case, the general opinion is that such measures should be temporary (that is, with sunset clauses).

Improving the framework for restructuring. Even when adequate for normal times, a revamped bankruptcy and restructuring framework might not be sufficient during a systemic crisis given the coordination problems and weaknesses in other aspects of the institutional framework. Thus governments have created special frameworks for corporate restructuring, such as the "London rules" first used in Mexico and then in several East Asian countries (Indonesia, Republic of Korea, Malaysia, Thailand). ${ }^{8}$ The London rules involve an out-ofcourt accord, under regular contract or commercial law, that all or most creditor institutions are coerced to sign. With such an accord, agreements reached among most creditors can often be enforced on other creditors without formal judicial procedures.

Arbitration with specific deadlines-and penalties for failing to meet the deadlines-can also be part of the accord, avoiding a formal judicial process to resolve disputes. ${ }^{9}$ The degree of such enhancements to the London rules has varied among countries. In East Asia the frameworks in Republic of Korea, Malaysia, and Thailand were the most conducive to out-of-court restructuring, while the framework in Indonesia was the least (Claessens, Djankov, and Klingebiel 2001). These differences appear to partly explain the variations in the speed of restructuring in these four countries.

The most far-reaching proposal for enhancing the restructuring framework is "super-bankruptcy" (or "super Chapter 11"), a temporary tool that allows corporate management to stay in place and forces debt-to-equity conversions (Stiglitz 2001). This tool can preserve firms' value as going concerns by preventing too many liquidations and keeping in place existing managers, who arguably most often know best how to run the firms. An important issue is when to call for a super Chapter 11 - that is, when is a crisis systemic, and who has the authority to call for such a suspension of

8 The London rules are principles for corporate reorganization first proposed in the United Kingdom in the early 1990 s. Because the rules were not designed for systemic corporate distress, countries have tightened them in various ways.

9 Out-of-court negotiations and bankruptcy or other legal resolution techniques are not the only ways of dealing with financial distress. Economists have been proposing alternative procedures for some time, centering on versions of an asset sale or cash auction. Cash auctions are easy to administer and do not rely on the judicial system (Hart and others 1997). While attractive from a theoretical perspective, these proposals have not had recent followers except Mexico in 1998. 
payments? Political economy factors should be taken into account, because some debtors could gain disproportionately from a suspension of payments. To date no country has taken this approach. ${ }^{10}$

Even with a better enabling environment, agents will likely be unable to triage corporations quickly and proceed with restructuring. The resulting debt overhang or deadlock in claims can be especially risky when institutions are weak, and can greatly increase the final costs to the public sector of resolving the crisis. Weak banks may continue to lend to corporations that are "too big to fail," partly as a way of gambling for resurrection, and so delay sustainable corporate restructuring. Owners of defunct enterprises may strip assets, leaving only liabilities for creditors. Even financially viable corporations may stop paying promptly if faced with an insolvent banking system.

In such cases it may be necessary in the short run to use hard budget constraints to limit the flow of resources to weak corporations from weak financial institutions or other sources. To increase credit to corporations that can actually repay and limit lending to weak corporations, it may also be necessary to have temporary across-the-board mechanisms for certain types of borrowers (such as small and medium-size enterprises) or certain activities (such as trade financing). The need for such blunter tools will increase with a country's institutional weakness. Indonesia's market-based approach to corporate restructuring, for example, seems to have had little impact and probably only led to further asset stripping.

Choosing a lead agent. As a next step it is often necessary for government to more directly support corporate restructuring. As with support for the financial system, it is essential to restructure strong and viable corporations, and not weak ones. But all too often, unviable corporations (such as those considered too big too fail) receive support instead of deserving, operationally viable corporations. This was the case with Korea's large chaebols and with

10 While bankruptcy laws differ considerably even among industrial countries, there has been a general move from more creditor-friendly regimes that are liquidationoriented toward more debtor-friendly regimes that are restructuring-oriented (Westbrook 2001).
Indonesia and Thailand's large family-controlled conglomerates. These firms ended up receiving disproportionately large financing during the first phase of the crisis while smaller firms lacked even working capital (Domac and Ferri 1999). Thus it is crucial to choose a lead agent that ensures proper analysis of corporations' prospects as well as durable operational and financial restructurings.

The main choice for the lead agent in restructuring is between the government and the private sector. Many approaches are possible. A centralized asset management corporation puts the government in charge. Recapitalization of private banks puts the banks in charge. Under other models investors and corporations can become the lead agent, with the government sharing the risks. Banks can work out nonperforming loans, for example, but with some stop-loss arrangements with the government. Or nonperforming loans can be transferred to a number of corporate restructuring vehicles that, though state-owned, can be privately run by asset managers with incentive stakes.

Most important is that the lead agent have the capital needed to absorb losses as well as the institutional capacity, incentives, and external enforcement mechanisms needed to effect restructuring. Undercapitalized banks, for example, will not be very effective restructuring agents. And without a working bankruptcy regime, private agents will not be able to force recalcitrant debtors to the negotiating table - as in Indonesia and in Thailand, where the restructuring of Thai Petrochemical Industry took three years.

Countries often choose a mix of these approaches when dealing with a systemic crisis. In 1995 Mexico tried both an asset management corporation and a more decentralized approach. The four East Asian crisis countries (Indonesia, Republic of Korea, Malaysia, Thailand) all eventually used asset management corporations, all used out-of-court systems for corporate restructuring, and most used, after some initial period, fiscal stimulus and monetary policy to foster economic growth. In addition, all enhanced, to varying degrees, their basic frameworks for private sector operations, including bankruptcy and corporate governance frameworks, liberalization of foreign entry in the financial and corporate sectors, and so on. But success has varied with the intensity of these measures (Claessens, Djankov, and Klingebiel 2001). 
Empirical evidence on these mechanisms is limited but tends to favor the decentralized model. A study of seven centralized approaches using asset management corporations found that most did not achieve their stated objectives with corporate restructuring (Klingebiel 2001). The study distinguishes corporate restructuring asset management corporations from bank rehabilitation asset management corporations. Two of the three corporate restructuring corporations did not achieve their narrow goal of expediting restructuring. Only Sweden's successfully managed its portfolio, acting in some instances as the lead agent in restructuring.

Rapid asset disposition vehicles fared somewhat better, with two of four-in Spain and the United States-achieving their objectives.

These successes suggest that asset management corporations can be effective, but only for narrowly defined purposes of resolving insolvent and unviable financial institutions and selling their assets. But even achieving these objectives requires many ingredients: a type of asset that is easily liquefied (such as real estate), mostly professional management, political independence, a skilled human resource base, appropriate funding, adequate bankruptcy and foreclosure laws, good information and management systems, and transparent operations and processes.

The findings by Klingebiel (2001) on asset management corporations are corroborated by a review of three East Asian countries (Dado 2000). The centralized asset management companies in Indonesia and Republic of Korea did not appear likely to achieve their narrow goal of expediting bank or corporate restructuring, while Malaysia's was relatively successful, aided by that country's strong bankruptcy system. Success has also varied when a mix of approaches is tried. In Mexico neither the asset management company nor the enhanced restructuring framework was effective, possibly because fundamental reforms were lacking (Mexico's bankruptcy regime, for example, was not revamped until four years after its crisis). Export-led growth appears to have led Mexico's recovery after 1995 (though growth did not resolve banking problems; see Krueger and Tornell 1999).

Dado and Klingebiel (2000) analyze decentralized restructuring in seven countriesArgentina, Chile, Hungary, Japan, Norway, Poland, and Thailand. They find that the success of this approach depended on the quality of the institutional framework, including accounting and legal rules, and on initial conditions, including the capital positions of banks and ownership links. In Norway the government built on favorable initial conditions to attain a solid overall framework for the decentralized approach. The biggest improvement to the overall framework was made in Chile, with favorable results. Poland and Hungary ranked behind Chile, though Poland improved its framework much faster than Hungary. Thailand made little progress on strengthening its framework. In Japan, despite many reforms to the overall framework, efforts remained blocked by large ownership links. And Argentina relied solely on public debt relief programs and did not change its overall framework for restructuring.

Changing ownership structures. Just as a crisis can offer a window for structural reform, it can provide an opportunity to reform a country's ownership structures. As a direct party to the restructuring process, the state often becomes the owner of defunct financial institutions and corporations. This development severely complicates the resolution of the crisis, because government may not have the right incentives or capacity to effect the needed operational and financial restructuring. At the same time, large indirect ownership by the state of the financial and corporate sectors provides an opportunity to change ownership structures as part of restructuring. This move can have several benefits.

First, the changes can correct ownership structures that contributed to the crisis and so help prevent future crises. To the extent, for example, that ownership concentrated in the hands of a few families contributed to the crisis-as argued by some for East Asia-government can try to widen ownership structures.

Second, government can try to obtain political support for restructuring by reallocating ownership. " One option is to reprivatize financial institutions or corporations in a way that

11 Regardless of the changes in ownership and the relationships between debtors and creditors, the government may want to create a special social safety net for laid-off workers to help sustain political support for restructuring over time. See Levinsohn, Berry, and Friedman (forthcoming) for the case of Indonesia. 
redistributes ownership among the general public or employees of the restructured institution. Another option is to use some of the state ownership to endow unfunded pension obligations from a pay-asyou-go system. In this way government can create ownership structures that over time will reinforce its reforms.

Third, changing ownership structures can introduce third parties who have better incentives and skills in restructuring individual corporations and determining financial relief. One option is to transfer nonperforming loans to a fund jointly owned by private and public shareholders, but with the private stake having lower seniority. Private shareholders in the fund would then have the right incentives when deciding on the financial viability of a corporation, but without having full formal ownership of the assets. Public resources would be provided only when all parties-creditor banks, other creditors, new private investors, the government, and the private shareholders in the fund-had reached agreement with the corporation.

Pursuing supportive macroeconomic policies. Another common theme in the literature is that corporate restructuring should occur in the context of supportive macroeconomic policies. The right macroeconomic policies (fiscal and monetary) can speed the recovery of overall activity and corporate output. The appropriate fiscal stance has been extensively reviewed, especially in the context of the East Asian crisis. A review by the International Monetary Fund suggests that East Asian countries' fiscal stance was too tight initially (Lane and others 1999). The appropriate monetary stance has been more controversial and is still being debated (see Drazen forthcoming and Cho and West forthcoming), but mainly in terms of defending the exchange rate.

An important related aspect is the effect on the corporate sector through a possible credit crunch. Microeconomic-based empirical literature suggests evidence of a credit crunch early in the East Asian crisis (Claessens, Djankov, and Xu 2000; Colaco, Hallward-Driemeier, and Dwor-Frecaut 2000; Dollar and Hallward-Driemeier 2000). The crunch was likely the result of tighter capital adequacy requirements and the monetary policies being pursued. More generally, it has been found that while tighter capital adequacy rules have minimal effects on aggregate credit provision, borrowers from weak banks are affected by tighter regulation and supervision (BIS 1999). Given the unbalanced financial systems in East Asia-where banks dominate and little alternative financing was available, and many banks were fragile even before the crisis (Claessens and Glaessner 1997) - it is likely that, at least initially, banking weaknesses and tighter regulation and supervision led to a credit crunch for East Asian corporations (Domac and Ferri 1999). Following this initial crunch, corporations may have ended up with a debt overhang, with a consequent need for financial restructuring.

\section{Conclusion}

The literature on systemic restructuring emphasizes the need for governments to actively intervene to overcome the many coordination problems in a systemic crisis and to relieve the shortage of financial capital, both of which impede progress with case-by-case restructuring. The core issue in dealing with a systemic crisis then becomes how to resolve coordination issues while preserving or enhancing incentives for normal, market-based restructuring and transactions. Achieving both goals requires consistent government policies, both among issues and sectors, and over time.

The literature also stresses that fiscal and monetary policies have to support the recovery process in a systemic crisis. Policies must strike the right balance between supporting the exchange rate and avoiding a serious credit crunch created by high interest rates. Supportive policies also cover other dimensions, such as the strictness of capital adequacy requirements and whether an allowance should be made for automatic rollover of payments by small and medium-size enterprises during the early phases of a crisis. As extensively debated in the context of the East Asian crisis and earlier (for example, following Chile's 1982 crisis), these supportive policies have not always been in place during systemic crises.

Especially during the containment phase of a systemic crisis, but also afterward, governments have to balance achieving stability with aggravating moral hazard. One dimension is avoiding the extension of government guarantees of financial institutions' liabilities, which can create moral hazard and reduce freedom in future loss allocations. Another dimension is the closing or suspension of some financial institutions. Though it 
Consistent reform is also needed for public recapitalizations. Any public recapitalization of banks must take into account the availability of fiscal resources. In several crisis countries the recapitalization of financial institutions with government bonds did not restore public confidence because limited fiscal resources were available to back the bonds. A related intertemporal consistency issue in any crisis is government credibility. We did not address this issue directly in this chapter, but ex ante consistency is a precondition for credibility.

Finally, approaches to restructuring must be consistent with a country's institutional capacity. Institutional deficiencies can rule out approaches in some countries that may be best practices in other countries. These best practices can include heavy reliance on a market-based approach to corporate restructuring-where banks are recapitalized and asked to work out debtors. But where corporate governance and financial regulation and supervision are weak, such an approach may be a recipe for asset stripping or looting rather than sustainable restructuring. Thus emerging markets and industrial countries will need different approaches to systemic restructuring.
While many of these lessons are often mentioned in the literature we reviewed, best practice policies are often not applied. Mistakes can be made in the middle of a crisis. Afterward, it is easy to point out these inconsistencies. But even before there have been many clear cases of inconsistent financial restructuring programs. These inconsistencies usually develop because policymakers are trying to overcome political constraints, and it is hard to judge whether they do so in the most efficient manner. But inconsistencies can also reflect genuine differences of opinion among policymakers and advisers on what constitutes best practice-as with the need to guarantee all liabilities during the early stages of a crisis. The end result is similar, in that consistency is often lacking.

Government efforts to restructure need to take into account the political economy factors behind the causes of a crisis and its resolution. In this context there might be ways to change ownership structures in a systemic crisis so that recovery is expedited and a more sustainable outcome results. But while we lack complete understanding of systemic crises, we know even less about the political economy of systemic crises.

\section{References}

Baer, Herbert, and Daniela Klingebiel. 1995. "Systematic Risk When Depositors Bear Losses: Five Case Studies." In G. G. Kaufman, ed., Research in Financial Services: Private and Public Policy. vol. 7. Greenwich, Conn.: JAI Press.

BIS (Bank for International Settlements). 1999. "Capital Requirements and Bank Behaviour: The Impact of the Basle Accord." Working Paper. Basle Committee on Banking Supervision, Basel, Switzerland.

Bordo, Michael, Barry Eichengreen, Daniela Klingebiel, and Maria Soledad Martinez-Peria. 2001. "Is the Crisis Problem Growing More Severe?” Journal of Economic Policy (April).

Burnside, Craig, Martin Eichenbaum, and Sergio Rebelo. Forthcoming. "On the Fiscal Implications of Twin Crises.” In Michael Dooley and Jeffrey Frankel, eds., Managing Currency Crises. Proceedings of a National Bureau for Economic Research conference. Chicago, Ill.: University of Chicago Press.

Caprio, Gerard, and Daniela Klingebiel. 1996. "Bank Insolvencies: Cross-Country Experience." Policy Research Working Paper 1620. World Bank, Washington, D.C.

Cho, Dongchul, and Kenneth D. West. Forthcoming. "Interest Rates and Exchange Rates in the Korean, Philippine and Thai Exchange Rate Crises." In Michael Dooley and Jeffrey Frankel, eds., Managing Currency Crises. Proceedings of a National Bureau for Economic Research conference. Chicago, Ill.: University of Chicago Press.

Claessens, Stijn, and Thomas Glaessner. 1997. Are Financial Sector Weaknesses Undermining the East Asian Miracle? A Directions in Development book. Washington, D.C.: World Bank. 
Claessens, Stijn, Simeon Djankov, and Daniela Klingebiel. 2001. "Financial Restructuring in East Asia: Halfway There?" In Stijn Claessens, Simeon Djankov, and Ashoka Mody, eds., Resolution of Financial Distress. Washington, D.C.: World Bank Institute.

Claessens, Stijn, Simeon Djankov, and Ashoka Mody, eds. 2001. Resolution of Financial Distress. Washington, D.C.: World Bank Institute.

Claessens, Stijn, Simeon Djankov, and Lixin Colin Xu. 2000. "Corporate Performance in the East Asian Financial Crisis." The World Bank Research Observer 15 (1): 23-46.

Colaco, Francis, Mary Hallward-Driemeier, and Dominique Dwor-Frecaut. 2000. "Asian Corporate Recovery: A Firm-Level Analysis." In Dominique Dwor-Frecaut, Francis Colaco, and Mary Hallward-Driemeier, eds., Asian Corporate Recovery: Findings from Firm-Level Surveys in Five Countries. Washington, D.C.: World Bank.

Dado, Marinela. 2000. "Note on Centralized Asset Management Companies in Indonesia, Korea and Thailand." World Bank, Trust Funds and Cofinancing Department, Washington, D.C.

Dado, Marinela, and Daniela Klingebiel. 2000. "Decentralized, Creditor-Led Corporate Restructuring: Cross-Country Experience." World Bank, Financial Sector Strategy and Policy Department, Washington, D.C.

Dollar, David, and Mary Hallward-Driemeier. 2000. "Crisis, Adjustment, and Reform in Thailand's Industrial Firms." The World Bank Research Observer 15 (1): 1-22.

Domac, Ilker, and Giovanni Ferri. 1999. "The Credit Crunch in East Asia: Evidence from Field Findings on Bank Behavior." World Bank, East Asia and Pacific Region, Washington, D.C.

Dooley, Michael, and Jeffrey Frankel, eds. Forthcoming. Managing Currency Crises. Proceedings of a National Bureau for Economic Research conference. Chicago, Ill.: University of Chicago Press.

Dooley, Michael, and Sujata Verma. Forthcoming. "Rescue Packages and Output Losses Following Crises." In Michael Dooley and Jeffrey Frankel, eds., Managing Currency Crises. Proceedings of a National Bureau for Economic Research conference. Chicago, Ill.: University of Chicago Press.

Drazen, Allan. Forthcoming. "Interest Rate Defense against Speculative Attack as a Signal: A Primer." In Michael Dooley and Jeffrey Frankel, eds., Managing Currency Crises. Proceedings of a National Bureau for Economic Research conference. Chicago, Ill.: University of Chicago Press.

Edwards, Sebastian, and Jeffrey Frankel. Forthcoming. Preventing Currency Crises in Emerging Markets. Proceedings of a National Bureau for Economic Research conference. Chicago, Ill.: University of Chicago Press.

Eichengreen, Barry, and Andrew Rose. Forthcoming. "Does it Pay to Defend Against a Speculative Attack?" In Michael Dooley and Jeffrey Frankel, eds., Managing Currency Crises. Proceedings of a National Bureau for Economic Research conference. Chicago, Ill.: University of Chicago Press.

Foley, Fritz. 2000. "Going Bust in Bangkok: Lessons from Bankruptcy Law Reform in Thailand." Harvard Business School, Cambridge, Mass.

Haggard, Stephen. 2001. "The Political Economy of Financial Restructuring in East Asia." In Stijn Claessens, Simeon Djankov, and Ashoka Mody, eds., Resolution of Financial Distress. Washington, D.C.: World Bank Institute.

Hart, Oliver, Rafael La Porta Drago, Florencio Lopez-de Silanes, and John Moore. 1997. "A New Bankruptcy Procedure That Uses Multiple Auctions." European Economic Review 41: 461-73.

Honohan, Patrick, and Daniela Klingebiel. 2000. "Controlling the Fiscal Costs of Banking Crises.” Policy Research Working Paper 2441. World Bank, Washington, D.C. 
International Monetary Fund. Various editions. International Financial Statistics. Washington, D.C.

Klingebiel, Daniela. 2001. "The Role of Asset Management Companies in the Resolution of Banking Crises." In Stijn Claessens, Simeon Djankov, and Ashoka Mody, eds., Resolution of Financial Distress. Washington, D.C.: World Bank Institute.

Krueger, Anne, and Aaron Tornell. 1999. "The Role of Bank Restructuring in Recovering from Crises: Mexico 1995-98." NBER Working Paper 7042. National Bureau for Economic Research, Cambridge, Mass.

Lane, Timothy, Atish Ghosh, Javier Hamann, Steven Phillips, Marianne Schultze-Ghattas, and Tsidi Tsikata. 1999. "IMF-Supported Programs in Indonesia, Thailand and Korea." IMF Occasional Paper 178. International Monetary Fund, Washington, D.C.

Levinsohn, James, Steven Berry, and Jed Friedman. Forthcoming. "Impacts of the Indonesian Economic Crisis: Price Changes and the Poor.” In Michael Dooley and Jeffrey Frankel, eds., Managing Currency Crises. Proceedings of a National Bureau for Economic Research conference. Chicago, Ill.: University of Chicago Press.

Lindgren, Carl-Johan, Gillian Garcia, and Matthew I. Saal. 1996. Bank Soundness and Macroeconomic Policy. Washington, D.C.: International Monetary Fund.

Lindgren, Carl-Johan, Tomás J. T. Baliño, Charles Enoch, Anne-Marie Gulde, Marc Quintyn, and Leslie Teo. 2000. "Financial Sector Crisis and Restructuring: Lessons From Asia." IMF Occasional Paper 188. International Monetary Fund, Washington, D.C.

Park, Yung Chul, and Jong Hwa Lee. Forthcoming. "Recovery and Sustainability in East Asia." In Michael Dooley and Jeffrey Frankel, eds., Managing Currency Crises. Proceedings of a National Bureau for Economic Research conference. Chicago, Ill.: University of Chicago Press.

Sheng, Andrew, ed. 1996. Bank Restructuring: Lessons from the 1980s. Washington, D.C.: World Bank.

Stiglitz, Joseph. 2001. "Bankruptcy Laws: Some Basic Economic Principles.” In Stijn Claessens, Simeon Djankov, and Ashoka Mody, eds., Resolution of Financial Distress. Washington, D.C.: World Bank Institute.

Stone, Mark. 2000a. "The Corporate Sector Dynamics of Systemic Financial Crises." Policy Discussion Paper 00/114. International Monetary Fund, Washington, D.C.

—_ 2000b. "Large-Scale Post-Crisis Corporate Sector Restructuring." Policy Discussion Paper 00/7. International Monetary Fund, Washington, D.C.

Westbrook, Jay. 2001. "Systemic Corporate Distress: A Legal Perspective." In Stijn Claessens, Simeon Djankov, and Ashoka Mody, eds., Resolution of Financial Distress. Washington, D.C.: World Bank Institute.

World Bank. 2000. East Asia: Recovery and Beyond. Washington, D.C. 



\section{Controlling the Fiscal Costs of Banking Crises}

\section{Patrick Honohan and Daniela Klingebiel}

\begin{abstract}
Patrick Honohan is lead economist in the Development Economics Research Group at the World Bank. Daniela Klingebiel is senior financial economist in the Financial Sector Strategy and Policy Department at the World Bank. This chapter summarizes a paper with the same name published as World Bank Policy Research Working Paper 2441 in September 2000. The authors are grateful to Thorsten
\end{abstract}

Beck, Gerard Caprio, Stijn Claessens, Asli DemirgûçKunt, Danny Leipziger, Giovanni Majnoni, Sole Martinez, Eric Rosengren, David Scott, and participants at conferences at the Chicago (U.S.) Federal Reserve (Bank Structure Conference) and the World Bank for helpful comments, and to Marinela Dado, Andrea Molinari, and Pieter van Oijen for excellent research assistance.
$\mathrm{I}$ $\mathrm{n}$ recent decades most countries-rich and poor alike-have experienced systemic banking crises requiring major-and expensiveoverhauls of their banking systems. Banking crises not only hit government budgets with outlays that have to be absorbed through higher taxes (or lower spending), they are also costly in terms of forgone economic output.

When crises break, as typically revealed through audits uncovering widespread bank insolvencies or through liquidity squeezes and depositor withdrawals, governments are faced with the tasks of containment and resolution. Either of two broad approaches can be pursued. One is accommodating, involving measures such as liberal liquidity support to banks with cash-flow difficulties, guarantees to depositors and creditors of financial institutions, regulatory forbearance by tolerating violations of bank solvency and minimum capitalization rules, and debtor support schemes that prop up bank borrowers who might otherwise default. The other approach sticks to the rules, requiring banks to meet standard capitalization requirements or face official intervention that constrains their operations. The accommodating approach can restore or sustain depositors' confidence and buy time for the situation to correct itself. It is often thought that this approach saves taxpayers' money in the long run and limits the wider economic costs of a crisis. But the heightened moral hazard entailed by the accommodating approach can be just as costly-if not more so.

This chapter examines the empirical evidence on the two approaches. Specifically, it quantifies the extent to which fiscal outlays incurred in resolving bank distress can be attributed to crisis management measures adopted by governments in the early years of a crisis. It does so by analyzing some 40 crises from around the world, a sample representing all those for which data are available on both the fiscal costs of the crises and the nature of the crisis management policies pursued.

We find no evidence that accommodating policies reduce fiscal costs. Indeed, each of the accommodating measures examined-open-ended liquidity support, blanket deposit guarantees, regulatory forbearance, repeated (and thus initially inadequate or partial) recapitalizations, and debtor bailout schemes-appears to significantly increase the costs of banking crises. Using regression results to simulate the effects of these accommodating policies, we find that if the countries in our sample had not pursued any such policies, fiscal costs would have averaged about 1 percent of GDP-little more than one-tenth of what was actually spent. Moreover, there is no indication that incurring these higher costs reduced the scale of the output dips that followed the crises. But things could have been worse: had every country pursued all the above policies, the regression results imply that fiscal costs would have reached more than 60 percent of GDP.

Our interpretation of these findings is in terms of the moral hazard created by accommodating policies. Our model also takes into account the independent role of macroeconomic shocks in contributing to and revealing bank insolvencies, as well as the fact that a bad resolution strategy can be more damaging when the origins of a crisis are primarily microeconomic.

The next section reviews the nature and extent of the costs of banking crises. The chapter then discusses the different tools for resolving crisesthat is, the choice between strict and accommodating policies. After that we present empirical evidence on the extent to which costs are 
influenced by these policy choices. The final section concludes.

\section{The costs of banking crises}

In the past quarter-century no type of country has managed to avoid costly banking crises: banking system failures have been at least as prevalent in developing and transition economies as in industrial countries. Since the late 1970 s, 113 systemic banking crises have occurred in 93 countries, and 50 borderline crises have arisen in 44 countries (Caprio and Klingebiel in this volume).

Governments - and thus ultimately taxpayershave shouldered most of the direct costs of these crises. These costs have been large: in our sample of 40 countries, governments spent an average of nearly 13 percent of GDP cleaning up their financial systems (figure 1 shows some of the higher costs in

\section{Figure 1}

\section{Fiscal costs of banking crises}

Percentage of GDP

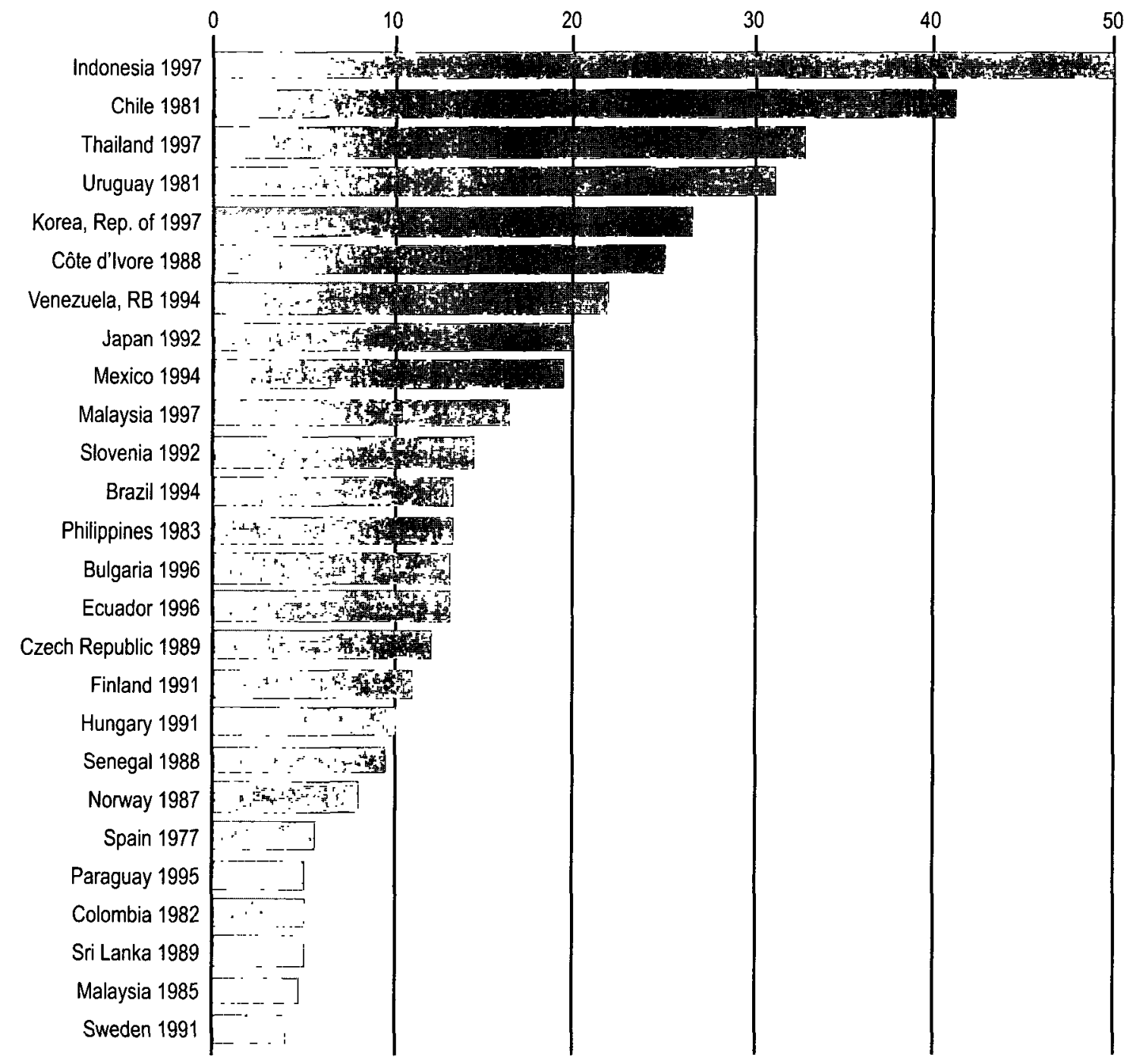


the sample). Costs were even higher (just over 14 percent of GDP) in developing countries. And some banking crises have been far more costly: in the early 1980s Chile's crisis cost 41 percent of GDP, and Argentina's cost 55 percent. Many of the costs of East Asia's recent financial crisis-estimated at 25-50 percent of GDP for the three hardest-hit countries (Indonesia, Republic of Korea, and Thailand) - will ultimately fall on government budgets. Despite their small economies, developing countries have suffered cumulative fiscal costs of more than \$1 trillion. Among industrial countries, Japan's drawn-out banking crisis has been the costliest.

Fiscal outlays are not the only economic costs of bank collapses. Indeed, to the extent that bailing out depositors amounts to a transfer from taxpayers to depositors, this is not even a net economic cost. But when a government makes a bank's claimants whole, its net costs tend to be correlated with the true economic costs. For one thing, the losses covered-which are caused by bad loan decisionsreflect wasted investible resources. Furthermore, a government's assumption of large, unforeseen bailout costs can destabilize fiscal accounts, triggering high inflation and a currency collapsecostly in themselves - as well as adding to the deadweight cost of taxation.

Moreover, fiscal costs do not include the costs borne by depositors and other creditors of failed banks (in some cases) and do not take into account the burden imposed on depositors and borrowers by the higher interest rate spreads that result from bad loans left on banks' balance sheets. In addition, fiscal costs do not reflect the costs of granting borrowers some monopoly privilege or other means to improve their profits and so repay their loans. Finally, estimates of fiscal costs do not capture the slowdown in economic activity that occurs when resources are driven out of the formal financial sector (into less efficient uses) and stabilization programs are derailed.

Estimating the fiscal costs of banking crises is not easy. There is no universal methodology, and obtaining the underlying components of the information required is usually problematic. Such costs typically arise through:

- Defaults on liquidity loans made by the monetary authority to a bank that proves to be insolvent.
- Bond or equity injections into an insolvent bank to restore its capital or make it salable to a sound bank; this is often done by buying part of the bank's loan portfolio at face value even though the recoverable value of the loans is much lower.

- The capitalized value of subsidized loans to insolvent banks or their borrowers.

- Payouts to depositors and other claimants, including foreign creditors. ${ }^{1}$

Most of our data on these costs come from evaluations made when a crisis has been detected and is being contained. They represent estimates of the net present value of prospective government outlays to restore banks' capital positions and to make depositors and creditors whole in cases where the government has extended guarantees to them.

While it is hard to obtain reliable data on the fiscal costs of banking crises, it is even harder to pinpoint the other dimensions of crisis costs. Attempts have been made to roughly estimate the additional flow economic costs, typically by comparing actual output with some hypothetical "no crisis" output path. But it is extremely difficult to guess what part of an output slump is caused by a banking crisis - a latent banking crash often becomes evident only when it is triggered by an exogenous economic shock that also directly contributed to recession. IMF (1998) offers one widely used approach to estimating the costs of the output dips that follow banking crises. ${ }^{2}$ Using this measure, output dips are correlated with measured fiscal costs and on average are of the same order of magnitude (figure 2). ${ }^{3}$

Examining the influence of policies on fiscal costs is of interest regardless of whether fiscal costs are a good measure of total crisis costs. But if

1 These avenues do not reflect the net fiscal flows to banking systems. Outside crisis times, repressed banking systems often involve a sizable flow of resources to the government.

2 Hoggarth, Reis, and Saporta (forthcoming) discuss alternative ways of measuring the subsequent output dip.

3 If three outliers are discarded, the correlation is 0.7 , and a regression line implies an approximate one-toone relationship between flow output costs and fiscal costs. 


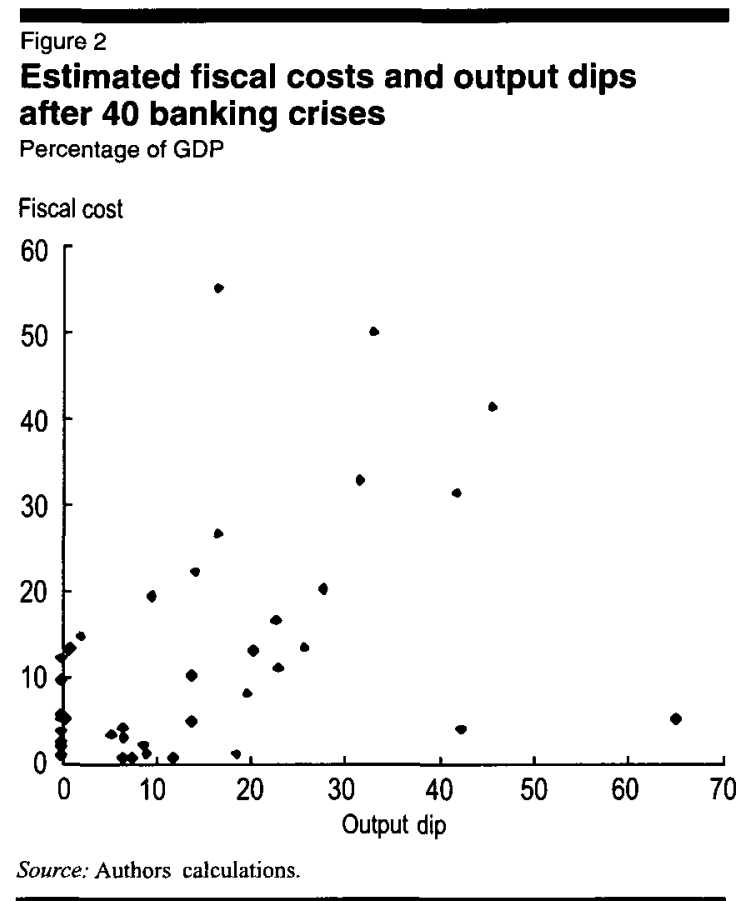

incurring fiscal costs helps reduce other crisis costs, then the policy implications would be quite different. In what follows we use the IMF (1998) approach to examine the influence of accommodating policies on crisis-induced output dips. There is no indication that such policies reduce such dips; some accommodating measures actually increase them.

\section{Accommodating and strict policies for resolving crises}

Although all banking systems are subject to ongoing supervision, awareness of emerging solvency problems typically triggers intensified management. Starting with a diagnosis of the scope of the crisis - especially whether it should be considered systemic - the authorities make a series of decisions ending with actions such as closing financial institutions, nationalizing them, liquidating them, disposing of their assets, and so on. There are many possible policy responses to banking distress, and the right decisions depend on factors such as the causes of the crisis, other prevailing conditions, and political constraints facing the regulatory authorities.

It is convenient to distinguish between policies for the short-term containment phase, while the crisis is unfolding, and those for the rehabilitation and restructuring phase. For both phases policy choices can be strict or more accommodating and gradual. In general, strict policies emphasize decisive preventive action. A gradual approach can be defended when the authorities have other ways of limiting further risk taking.

\section{Containment phase}

In the early stages of a financial crisis, governments typically implement policies aimed at restoring public confidence in the banking system to minimize repercussions on the real sector. As they struggle to contain the crisis, governments face (among others) two key strategic questions:

- Should open-ended liquidity support be extended to all financial institutions, including insolvent ones?

Should blanket guarantees be provided to depositors and creditors of financial institutions (in times of severe disruption) to stem a loss of confidence in the system as a whole?

Open-ended liquidity support. The classic doctrine is that central banks should abstain from providing banks with open-ended emergency liquidity support unless they are satisfied that the banks are viable and oversight is adequate. Proponents of this view point out that governments have often used liquidity support to delay crisis recognition and to avoid intervening in de facto failed institutions. They argue that open-ended liquidity support is doomed to fail because manager and shareholder incentives shift when a financial institution becomes insolvent. Thus, unless public loans to insolvent banks are conditioned on restructuring and recapitalization, they prolong such institutions' ability to gamble for resurrection, facilitate continued financing to lossmaking borrowers, and allow owners and managers to engage in looting. The alternative view recognizes that crisis conditions make it nearly impossible to distinguish between solvent and insolvent institutions, and argues that a generalized crisis leaves the authorities with little choice but to extend liquidity support.

Blanket deposit guarantees. A second contentious point is whether governments should extend explicit blanket guarantees to depositors and creditors immediately after the onset of a crisis, to stem the loss of confidence in the financial system. Some 
analysts take a strict line here as well, arguing that guarantees-if they are credible--reduce large creditors' incentives to monitor financial institutions, providing ready funds for managers and shareholders to use in gambling to resurrect insolvent banks. They also point out that extensive guarantees limit governments' maneuverability in allocating future losses, with the result that they may end up absorbing most of the costs. Others reason that, by extending timely and temporary guarantees, the authorities can avoid the much greater fiscal and economic costs of a widespread panic, such as could be triggered or exacerbated by the closing of a few banks.

\section{Rehabilitation and restructuring phase}

During rehabilitation and restructuring the authorities are focused on restoring the capital position of banks and resolving bad assets. Key strategic questions include:

- Is it safe for governments to engage in implicit or explicit regulatory forbearance so that banks can strengthen their capital base over time through higher profits?

- Should the authorities insist on accomplishing complete recapitalization immediately, or can recapitalization be done in stages?

- Should governments intervene to help borrowers cover their debts?

Regulatory forbearance. If banks still have a franchise value, they could in principle restore their capital over time by retaining profits. But such a flow solution allows banks to function while undercapitalized and so typically requires forbearance on strict application of prudential regulatory requirements. Forbearance is a matter of degree. In its most accommodating form, banks known to be insolvent are allowed to remain open. Less accommodating forbearance policies include allowing severely undercapitalized banks to remain open under existing management or temporarily relaxing any of a range of other regulations--such as loan classification and loan loss provisioning requirements.

Opponents of regulatory forbearance point to the apparent contradiction of relaxing prudential requirements just when they bite, and again note the danger of allowing insolvent or undercapitalized banks to gamble for resurrection. Proponents of forbearance counter that regulation should depend on what state banks are in, and that relaxing regulation in response to macroeconomic downturns can provide better ex ante risk sharing as well as shelter bank customers from the disruptions to financial services (including credit crunches) that may result from widespread bank suspensions and closures.

Repeated recapitalizations. Instead of relying on a flow of future profits, stock solutions immediately inject capital, and are supported by the government and aimed at restoring the solvency of viable but insolvent or marginally solvent institutions. If recapitalization needs to be repeated, this suggests that not enough was done the first time, and thus that the bank was allowed to operate without enough capital. Opponents of repeated recapitalizations point to the moral hazard involved.

Banks' incentives to collect their loans and borrowers' incentives to repay are undermined as both await the next bailout, increasing budget costs and delaying corporate restructuring. Proponents of partial (and hence repeated) recapitalizations point to the fiscal pressures that can result from immediate recognition of the full need for additional capital.

Debtor bailouts. If bank bailouts are politically unpopular, an indirect way of relieving a crisis - and possibly restarting real economic activity-is introducing a public debt relief program for bank borrowers. Critics argue that, in addition to obvious moral hazard, such programs risk being open-ended, attracting borrowers who never would have been able to repay even in good times and diverting investible resources to uncreditworthy firms. ${ }^{4}$ Proponents of public debt relief schemes contend that they are a good tool for mitigating external shocks beyond the control of corporations.

\section{Empirical evidence}

Having considered the various intervention and resolution policies that governments can adopt and that may influence the fiscal costs of a crisis, we

4 In the empirical analysis we also experimented with a dummy for the use of asset management companies (Klingebiel 2000) and a freeze on deposits. Both of these dummies were never significant, so they are not further discussed here. 
now turn to the empirical evidence. Perhaps there are no universal solutions to these issues: country circumstances may determine the right policy choices. Still, we can examine the statistical relationship between policy choices and crisis costs.

Modeling the cross-country variation in fiscal costs requires us to take into account both policy variables and exogenous variables. The severity of a triggering macroeconomic recession and other factors unrelated to management and resolution policies can obviously increase financial distress independently of the policies adopted, so we need to take that into account to avoid assigning too much importance to policy. But resolution policies can also deepen losses. Their influence will depend on the extent to which a crisis is caused by microeconomic factors, including management deficiencies in banks. Finally, governments can choose to cover more or less of the overall losses. Thus the estimating equation may need to include macroeconomic factors as controls, as well as policy variables. Furthermore, the size of the coefficients may depend on whether microeconomic weaknesses are pervasive. This section describes the data we assembled to estimate these effects and reports on the regression results.

\section{Sample and variables}

It was a major challenge to develop a dataset that identified not just regulatory policies and other causal factors but also actual fiscal costs, for which most data sources are not very reliable. The sources and methods for the data are described in the appendix.

The sample consists of 34 countries ( 25 of them developing or transition economies, with 9 in Latin America, 6 in Asia, 5 in Eastern Europe, and 5 in Africa or the Middle East) that experienced significant fiscal costs from bank failures between 1970 and 2000 . Why these countries? Simply because they are the entire set for which we were able to gather sufficient information on both regulatory practices and fiscal costs. Six of the countries experienced two distinct crisis episodes. These episodes are treated separately, giving 40 distinct country experiences.

The variable to be explained is the estimated total direct fiscal cost of the banking crisis as a percentage of GDP. ${ }^{5}$ The explanatory variables fall into three groups: crisis resolution policy variables, macroeconomic indicators, and indicators of the nature of the bank failures. (Fuller definitions are provided in the appendix.)

Crisis resolution policy variables. In line with the discussion in the previous section, we used six variables measuring resolution policy tools (table 1). These are all dummy variables with a value of 0 when policy was strict and 1 when policy was more relaxed:

- LIQSUP indicates whether central banks or other government agencies (such as deposit insurance agencies) provided liquidity support to financial institutions. It has a value of 1 if the government provided open-ended, extensive support (often at below-market rates) to financial institutions regardless of their financial position. Support is open-ended and extensive if it was extended longer than a year and was greater than total banking capital (as happened in 23 of our 40 cases)-at which point it is no longer temporary liquidity support but rather solvency support.

- GUAR has a value of 1 if the government issued an explicit blanket guarantee to depositors and creditors after the onset of the crisis or if market participants were implicitly protected from losses because public banks accounted for at least 75 percent of the market (also 23 cases).

- There are two measures of regulatory forbearance. $F O R B-A$ has a value of 1 if some banks were permitted to continue functioning despite being technically insolvent ( 9 cases). $F O R B-B$ has a value of 1 if either $F O R B-A$ was applied or some prudential bank regulationssuch as for loan classification and loan loss provisioning-were suspended or not fully applied ( 26 cases).

- An additional indicator of forbearance, REPCAP, has a value of 1 if banks were repeatedly

5 The results reported use the functional form $\log y$. With this transformation the skewness of the dependent variable is greatly reduced, but it has the drawback that it is undefined as costs approach 0 . Alternative functional forms such as $\log (1+\cos t)$ and $\cos t /(1+$ cost) gave qualitatively similar results. 


\begin{tabular}{lc}
\hline $\begin{array}{l}\text { Table } 1 \\
\text { Government responses to } \\
\mathbf{4 0} \text { banking crises } \\
\text { Policy tool (name of variable) }\end{array}$ & Number of times used \\
\hline Liquidity support (L/QSUP) & 23 \\
\hline Blanket guarantee (GUAR) & 23 \\
\hline Forbearance type A (FORB-A) & 9 \\
\hline Forbearance type B (FORB-B) & 26 \\
\hline Repeated recapitalizations (RECAP) & 9 \\
\hline Public debt relief program (PDRP) & 9 \\
Source: Honohan and Klingebiel (2000). & \\
\hline
\end{tabular}

recapitalized. Such events suggest that the initial recapitalization was inadequate and effectively amounted to capital forbearance ( 9 cases).

- Finally, $P D R P$ has a value of 1 if the government implemented an across-the-board public debt relief program. Such programs can be seen as a further form of accommodation likely to generate moral hazard ( 9 cases).

Thus among these tools the most common in our sample were regulatory forbearance (type B), liquidity support, and blanket government guarantees on bank deposits. But authorities were selective when being accommodating, so policy choices are not strongly correlated (table 2). That means, for example, that governments that used liquidity support did not necessarily use any particular other policy tool.

Macroeconomic indicators. Many crises were triggered or exacerbated by exogenous macroeconomic conditions. We explored a variety of indicators to control for the impact of macroeconomic shocks on fiscal costs (table 3). From this set two were consistently significant: the real deposit interest rate (REALINT) and the change in equity prices (STOCKPRICE, taken to the third power to increase the contribution of large values).

Indicators of the nature of the bank failures. We use a composite variable, MICRO, that aggregates the indicators of microeconomic management described in the appendix. This variable is used as a slope dummy with some of the policy variables.

$\begin{aligned} & \text { Table } 2 \\
& \text { Correlation matrix for individual } \\
& \text { policy tools } \\
& \\
& \text { LUQSUP }\end{aligned}$
\begin{tabular}{lrrrrrrr}
\hline GUSUAP & 1 & 0.28 & -0.02 & 0.22 & 0.10 & 0.10 \\
\hline GUAR & 1 & -0.14 & 0.32 & 0.46 & -0.02 \\
\hline FORB-A & & 1 & 0.27 & -0.14 & 0.28 \\
\hline FORB-B & & & 1 & 0.27 & 0.27 \\
\hline REPCAP & & & & 1 & 0.00 \\
\hline PDRP & & & & \\
Source: Honohan and Klingebiel (2000).
\end{tabular}

\section{Regression results}

Starting with the parameter estimates for the macroeconomic indicators, we find that macroeconomic difficulties-as indicated by high real interest rates and falling equity prices-tend to increase the fiscal costs of a banking crisis. But these variables are mainly included to ensure that the omission of macroeconomic factors does not bias the estimate of policy variables.

When interpreting the main results, bear in mind that the sign of the policy parameters is set so that a positive coefficient indicates that an accommodating policy choice increased fiscal costs. The main finding is that every significant coefficient is positive. In other words, we found no specification where an accommodating policy choice significantly reduced fiscal costs. Varying the specification by including or excluding explanatory variables does not significantly affect the size of the coefficients. This outcome also holds whether or not the macroeconomic variables are included (Honohan and Klingebiel 2000).

LIQSUP and the two FORBS are the most consistently significant explanatory variables; GUAR is also consistently significant. Replacing $F O R B-B$ by its product with the dummy MICRO achieves a small improvement, modestly supporting the hypothesis that using regulatory forbearance as a crisis resolution tool will result in even higher fiscal costs in countries with weak microeconomic environments (Honohan and Klingebiel 2000).

The policy message from these results seems clear: open-ended liquidity support, regulatory forbearance, and a blanket guarantee for depositors and creditors all significantly contribute to the fiscal cost of banking crises. 
Table 3

Macroeconomic, microeconomic, and government intrusion indicators before the onset of $\mathbf{4 0}$ banking crises

Percent

Indicator

Quartile I

Median

Quartile III

Max/Min

Macroeconomic

Real deposit interest rate*a

\begin{tabular}{lcccr}
\hline Real GDP growth* & -1.6 & -0.2 & 0.9 & 9.3 \\
\hline Change in equity prices* & -27.0 & -10.8 & 20.0 & 211.0 \\
\hline Current account/GDP & -5.8 & -3.9 & -0.6 & 2.3 \\
\hline Fiscal balance/GDP & -4.7 & -1.2 & 0.3 & 5.1 \\
\hline Change in terms of trade* & -5.7 & -0.6 & 3.4 & 21.2 \\
\hline Short-term external debU/GDP* & 56.3 & 14.4 & 9.2 & 7.9
\end{tabular}

Microeconomic

Growth in credit/GDP

\begin{tabular}{lrrr}
407.0 & 214.0 & 147.0 & 116.0 \\
\hline 190.5 & 138.9 & 111.4 & 87.6
\end{tabular}

Loans/deposits*

47.3

\begin{tabular}{llccc} 
Bank reserves/deposits & 47.3 & 16.7 & 8.4 & 4.4 \\
\hline Share of government in total bank claims & 91.3 & 17.6 & 11.0 & 4.0 \\
\hline Bank borrowing from central bank/total bank deposits & 80.0 & 15.9 & 6.0 & 2.7
\end{tabular}

Bank reserves/deposits

* Average for one year before crisis.

Average for two years before crisis.

a. Also a microeconomic indicator.

Source: World Bank.

There is one obvious potential problem of simultaneity here: really big crises may have triggered the adoption of policies such as blanket guarantees or liquidity support (especially if these policies can be seen to some extent as being analogous to the government burying its head in the sand) in countries that otherwise relied on strict policies. To verify that our results are not contaminated by such reverse causality, we used an instrumental variables approach.

Our two types of predetermined instruments used data on the political and institutional environment and on timing. The political and institutional data are those published by the International Country Risk Guide measuring corruption in government (CORRUPT) and the tradition of law and order (LAWORDER). These were used because it is assumed that countries with weak institutions, as measured by either variable, are more likely to adopt accommodating policies.

The timing instruments are dummy variables for the years when crises began (there are $14 \mathrm{such}$ years; each dummy takes a value of 1 for countries whose crisis began that year, 0 otherwise). The time dummies could be valid instruments to the extent that the choice of accommodating policies in a particular year is influenced by global trends or overall world conditions.

According to Honohan and Klingebiel (2000), two-stage least squares estimates of the main equations using these instruments come out close to the ordinary least squares results. This finding implies that the predicted degree of accommodation from the first-stage regressions is just as strong a predictor of fiscal costs as the actual degree of accommodation. A regression of the residuals on the instruments is not significant, providing some reassurance that the instruments are indeed predetermined. In all, then, this evidence suggests that reverse causality is not a problem for the interpretation of our results.

We also experimented with alternative functional forms. Several different forms give a similar fit without dominating the one shown (though as noted below, the exact functional form 
does have implications for the size of out-of-sample predictions).

\section{Scale of the cost implications}

Our empirical findings show that accommodating policies significantly increase the fiscal costs of banking crises. If we were to take the regression results literally and simulate the effects of uniformly strict and uniformly accommodating policy packages, we would obtain rather extreme results. These results imply that a crisis country that did not provide open-ended liquidity support, blanket deposit guarantees, regulatory forbearance, repeated recapitalizations, or debtor bailouts would have incurred a fiscal cost of about 1 percent of GDP. On the other hand, a crisis country that provided all these forms of support would have a predicted fiscal cost of more than 60 percent of GDP (Honohan and Klingebiel 2000). But because they are calculated beyond the range of the sample, and taking into account their sensitivity to the functional form of the equation, these limiting projections should probably not be taken too literally.

Still, more realistic calculations showing the estimated impact of each policy tool-assuming the other tools are used with their actual frequencyalso show sizable effects (table 4). These calculations indicate that the most expensive accommodating measures are liquidity support and the various forms of forbearance, each of which costs several percentage points of GDP. The

\begin{tabular}{|c|c|}
\hline \multicolumn{2}{|c|}{$\begin{array}{l}\text { Table } 4 \\
\text { Estimated fiscal costs of } \\
\text { accommodating policy tools }\end{array}$} \\
\hline $\begin{array}{l}\text { Policy tool } \\
\text { (percentage of cases where used) }\end{array}$ & $\begin{array}{l}\text { Cost of adopting each tool } \\
\text { (percentage of GDP) }\end{array}$ \\
\hline Forbearance type A (24) & 6.7 \\
\hline Repeated recapitalizations (24) & 6.3 \\
\hline Liquidity support (58) & 6.3 \\
\hline Forbearance type B (84) & 4.1 \\
\hline Public debt relief program (21) & 3.1 \\
\hline Blanket guarantee (55) & 2.9 \\
\hline \multicolumn{2}{|c|}{$\begin{array}{l}\text { Note: The table shows how much each accommodating measure can add } \\
\text { to fiscal costs. For example, permitting insolvent banks to stay open } \\
\text { (forbearance type A; see text) raises predicted fiscal costs by } 6.7 \text { percent } \\
\text { of GDP twice the sample mean (each calculation uses the sample mean } \\
\text { value of the other variables). }\end{array}$} \\
\hline Source: Honohan and Klingebiel $(2000$ & \\
\hline
\end{tabular}

equation predicts that if deposit guarantees, one form of forbearance, and repeated recapitalizations are used, not extending liquidity support could halve the expected fiscal cost.

Another caveat worth repeating is that the final regressions do not include variables measuring policies in place before the interventions considered here. To the extent that such policies are important (and to the extent that they would be correlated with the included policy variables), their omission may bias the estimated coefficients of the included policy variables. Accommodating pre-crisis policies that allowed financial institutions to take big risks might well be associated with accommodating intervention and resolution policies that raised postcrisis costs.

\section{Is there a tradeoff between fiscal costs and economic recovery?}

We also explored whether there was an obvious tradeoff between fiscal costs and subsequent economic growth. In other words, did countries that used accommodating policies experience faster macroeconomic recovery? Using a standard approach to measure the size and duration of the output dips following the crises (IMF 1998), regressions using the same structure as for fiscal costs fail to uncover evidence that this was the case (Honohan and Klingebiel 2000). Except for liquidity support, all the policy variables proved insignificant. And for liquidity support, the positive coefficient indicates that such support actually appears to have prolonged crises, because recovery took longer. Furthermore, the estimated output dip was bigger.

\section{Conclusion}

In this chapter we have made a first attempt to understand whether and what kind of crisis resolution policies are effective in lowering the fiscal costs of banking crises. While much discussion suggests that most of the costs of banking crises come from exogenous shocks, we find evidence that resolution policies matter-and that strict resolution policies contain fiscal costs.

Of course, it may also be that the underlying policy philosophy that tends to generate strict policies is associated with an environment that helps contain costs before the recognition phasethat is, before a crisis is recognized as such. By the time containment and resolution policies come into 
play, some of the damage of an accommodating policy stance will have already been done.

But while we have emphasized intervention and resolution policies, it is not really possible to draw an unambiguous line between these and prevention policies. To the extent that prevention policies have been explicitly included, our estimates may somewhat exaggerate the role of intervention and resolution.

The data on which we depend are tentative, and one should not rely too heavily on the precise coefficient estimates. Still, the effects we model are statistically significant, have a consistent sign, and are economically large. In particular, open-ended liquidity support, regulatory forbearance, and a blanket guarantee for depositors and other creditors significantly contribute to the fiscal costs of banking crises. Countries that avoid these policies can expect to considerably cut the costs of future crises.

Containing and resolving banking crises is not easy, and the exact policy approach cannot be dictated by the results of a model simplified for econometric testing. We can hardly claim to have proven the best policy choices in all circumstances. Nevertheless, our findings clearly favor a strict approach to resolving crises, rather than an accommodating one. At the very least, they emphasize that regulatory authorities who choose an accommodating or gradual approach to an emerging crisis need to be sure that they have some other way of controlling risk taking.

\section{Appendix: Descriptions of variables and data}

\section{Dependent variables}

\section{Fiscal cost}

The dependent variable fiscal cost is the estimated net present value of the budget cost of the crisis based on official or expert assessments, expressed as a percentage of GDP (table A1). The first date shown for the crisis is the date when the existence of the crisis became publicly known. The fiscal cost figure includes both fiscal and quasi-fiscal outlays for financial system restructuring, including the cost of recapitalizing banks, bailout costs related to covering depositors and creditors, and debt relief schemes for bank borrowers.

Data on fiscal costs and crisis dates are from World Bank estimates assembled from published sources and from recent discussions with national experts. The estimates here draw on those reported by Caprio and Klingebiel (1996 and in this volume) and Lindgren, Garcia, and Saal (1996). Conflicts between sources have been reconciled with the help of country experts.

\section{Output dip}

Dips in output growth following banking crises are calculated using the approach of and data from IMF (1998), with updates for more recent crises (table A2). This approach calculates the output dip as the cumulative deviation of output from its previous trend growth during the duration of the dip, defined as the period over which the output growth rate remains below the trend value. As in IMF (1998), recovery time is 1 plus the duration of the dip (in years). As noted in the text, Hoggarth, Reis, and Saporta (forthcoming) propose alternative dip measures.

\section{Data on crisis resolution tools}

To characterize the main components of a crisis resolution strategy, we use dummy variables (shown in table A1) characterizing each government's approach along five dimensions:

- Issuance of a blanket government guarantee (GUAR). Did the government issue an explicit and unlimited guarantee for depositors and creditors, or were market participants implicitly protected because deposits in state-owned institutions accounted for more than 75 percent of banking deposits?

- Open-ended, extensive liquidity support to insolvent institutions (LIQSUP). Did the government or one of its agencies (typically a central bank or deposit insurance agency) provide open-ended, extensive liquidity support (at preferential rates) to financial institutions regardless of their financial standing? (Support is open-ended and extensive if it was provided for longer than a year and was greater than total banking capital.)

- Forbearance (FORB). Did the government forbear in either of the following progressively less liberal ways? Under forbearance type A, 


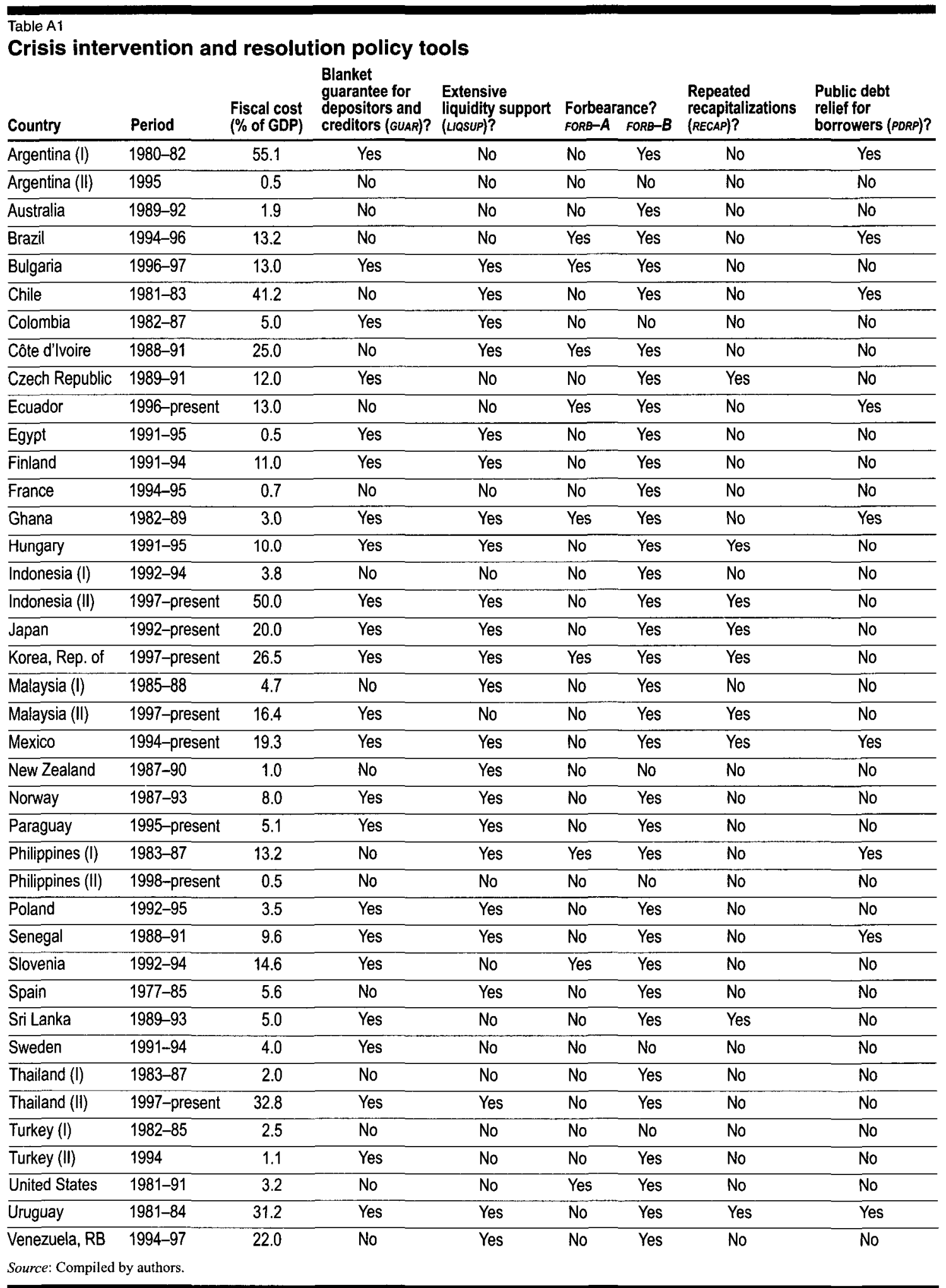


banks observed to be in open distress-such as those unable to pay depositors, with no access to the interbank market, or widely believed to be insolvent (except public banks)—are allowed to continue operating without any restrictions for at least a year. Under forbearance type B, either forbearance type A was applied or regulations (particularly those for loan classification and loan loss provisioning) are relaxed or the current regulatory framework is not enforced for at least a year.

- Repeated recapitalizations (REPCAP). Did banks undergo more than one round of governmentsponsored recapitalizations?

- Public debt relief program (PDRP). Did the government implement a broad debt relief program for corporations or other types of borrowers, including through an exchange rate guarantee program or rescue of corporations?

Data on these measures drew on the dataset from Caprio and Klingebiel (1996) and added countries and policy variables. Information on the policy variables came from official country sources, from the World Bank Regulatory Database (Barth, Caprio, and Levine 2001), from Garcia (1999) and other IMF reports, and from interviews with country experts. Complete data are available for 40 episodes involving 34 countries.

\section{Control variables}

We used data summarizing macroeconomic conditions, the regulatory and management

\begin{tabular}{|c|c|c|c|c|c|c|c|c|}
\hline Country & $\begin{array}{l}\text { Growth in } \\
\text { credit/GDP } \\
\text { (I) }\end{array}$ & $\begin{array}{l}\text { Real deposit } \\
\text { interest rate } \\
\text { (II) }\end{array}$ & $\begin{array}{l}\text { Loan } \\
\text { classification } \\
\text { (III) }\end{array}$ & $\begin{array}{l}\text { Enforcement } \\
\text { of creditor } \\
\text { rights }^{b} \text { (IV) }\end{array}$ & $\begin{array}{l}\text { Loan to } \\
\text { deposit ratio } \\
\text { (V) }\end{array}$ & $\begin{array}{l}\text { MICRO } \\
(0 \text { if mean of } \\
(\mathrm{I}-\mathrm{V} \geq \mathbf{2 . 4})\end{array}$ & $\begin{array}{l}\text { Output } \\
\text { growth dipc } \\
\text { (\% of GDP) }\end{array}$ & $\begin{array}{l}\text { Duration } \\
\text { of dipc } \\
\text { (years) }\end{array}$ \\
\hline Argentina (I) & 3 & 1 & 2 & 2 & 3 & 1 & 16.6 & 4 \\
\hline Argentina (II) & 1 & 2 & 3 & 4 & 2 & 0 & 11.9 & 3 \\
\hline Australia & 3 & 3 & 3 & 4 & 2 & 0 & 0 & 1 \\
\hline Brazil & 2 & . & 3 & 3 & 2 & 1 & 1 & 0 \\
\hline Bulgaria & 4 & 1 & 3 & . & 4 & 0 & 20.4 & 3 \\
\hline Chile & 1 & 3 & 3 & 4 & 1 & 0 & 45.5 & 9 \\
\hline Colombia & 3 & 2 & 2 & 1 & 3 & 1 & 65.1 & 5 \\
\hline Côte d'Ivoire & 4 & 1 & 1 & 2 & 1 & 1 & & \\
\hline Czech Republic & 2 & 3 & 1 & 3 & . & 1 & 0 & 1 \\
\hline Ecuador & 1 & 4 & 3 & 2 & 3 & 0 & 0.9 & 1 \\
\hline Egypt & 4 & 1 & . & 1 & 4 & 1 & 6.5 & 5 \\
\hline Finland & 3 & 2 & 4 & 4 & 1 & 0 & 23.1 & 7 \\
\hline France & 4 & 2 & 4 & 4 & 1 & 0 & 0 & 1 \\
\hline Ghana & 4 & 1 & 1 & 1 & 4 & 1 & 6.6 & 2 \\
\hline Hungary & 4 & 2 & 1 & 3 & 1 & 1 & 13.8 & 3 \\
\hline Indonesia (I) & 1 & 4 & 1 & 1 & 2 & 1 & 42.3 & 9 \\
\hline Indonesia (II) & 3 & 4 & 2 & 3 & 2 & 0 & 33.0 & 4 \\
\hline Japan & 2 & 2 & 4 & 3 & 2 & 0 & 27.7 & 9 \\
\hline Korea, Rep. of & 2 & 3 & 2 & 2 & 1 & 1 & 16.5 & 3 \\
\hline Malaysia (I) & 1 & 4 & 2 & 3 & 2 & 0 & 13.7 & 4 \\
\hline Malaysia (II) & 2 & 3 & 2 & 3 & 2 & 0 & 22.8 & 4 \\
\hline Mexico & 1 & 4 & 2 & 2 & 1 & 1 & 9.6 & 2 \\
\hline New Zealand & 2 & 2 & 4 & 2 & 4 & 0 & 18.5 & 7 \\
\hline Norway & 1 & 4 & 1 & 4 & 2 & 0 & 19.6 & 8 \\
\hline
\end{tabular}


environment affecting bank management (referred to as microeconomic indicators), and the degree of government intrusion:

- Macroeconomic indicators, as averages for one $\left.{ }^{*}\right)$ or two $(\dagger)$ years before the crisis year: real deposit interest rate* (also a microeconomic indicator), real GDP growth*, percentage change in equity (stock market) prices*, current account as a percentage of GDP $\dagger$, fiscal balance as a percentage of GDP $\dagger$, percentage change in the terms of trade*, and short-term external debt as a percentage of GDP*.

- Microeconomic indicators: growth in bank credit relative to GDP† (as proxy for relaxed credit risk standards), real deposit interest rate (possible proxy for financial system distress as banks bid up rates to stay afloat), loan classification rules (proxy for quality of regulation; see note to table A2), enforcement of creditor rights (proxy for the effectiveness of the legal system; see note to table A2), and average ratio of bank loans to deposits* (proxy for liquidity risk).

- Government intrusion indicators: bank reserves (cash plus with central bank) as percentage of deposits, share of government in total bank claims, and bank borrowing from central bank as a percentage of total bank deposits.

Each continuous control variable was normalized to zero mean and unit standard deviation. The variable $M I C R O$ is a composite of the microeconomic indicators: it takes a value of 1 when the country

\begin{tabular}{|c|c|c|c|c|c|c|c|c|}
\hline Country & $\begin{array}{l}\text { Growth in } \\
\text { credit/GDP } \\
\text { (I) }\end{array}$ & $\begin{array}{l}\text { Real deposit } \\
\text { interest rate } \\
\text { (II) }\end{array}$ & $\begin{array}{l}\text { Loan } \\
\text { classification" } \\
\text { (III) }\end{array}$ & $\begin{array}{l}\text { Enforcement } \\
\text { of creditor } \\
\text { rights }^{b} \text { (IV) }\end{array}$ & $\begin{array}{l}\text { Loan to } \\
\text { deposit ratio } \\
(V)\end{array}$ & $\begin{array}{l}\text { MICRO } \\
(0 \text { if mean of } \\
\mid-V \geq 2.4)\end{array}$ & $\begin{array}{l}\text { Output } \\
\text { growth dipe } \\
\text { (\% of GDP) }\end{array}$ & $\begin{array}{l}\text { Duration } \\
\text { of dipe } \\
\text { (years) }\end{array}$ \\
\hline Paraguay & 2 & 3 & 3 & 4 & 3 & 0 & 0 & 1 \\
\hline Philippines (I) & 3 & 3 & 2 & 1 & 1 & 1 & 25.7 & 5 \\
\hline Philippines (II) & 1 & 3 & 3 & 2 & 3 & 0 & 7.5 & 3 \\
\hline Poland & 2 & 1 & 1 & 2 & 4 & 1 & 0 & 1 \\
\hline Senegal & 4 & 4 & 1 & 1 & 1 & 1 & 0 & 1 \\
\hline Slovenia & . & 4 & 1 & 4 & 3 & 0 & 2.1 & 2 \\
\hline Spain & 3 & 1 & 1 & 2 & 4 & 1 & 0 & 1 \\
\hline Sri Lanka & 1 & 2 & . & 1 & 3 & 1 & 0.5 & 3 \\
\hline Sweden & 1 & 2 & 3 & 4 & 1 & 1 & 6.5 & 3 \\
\hline Thailand (I) & 2 & 3 & 1 & 1 & 3 & 1 & 8.7 & 2 \\
\hline Thailand (II) & 3 & 4 & 1 & 2 & 1 & 1 & 31.5 & 4 \\
\hline Turkey (I) & 3 & 1 & 1 & 4 & 4 & 0 & 0 & 1 \\
\hline Turkey (II) & 4 & 1 & 3 & 4 & 4 & 0 & 9.1 & 2 \\
\hline United States & 2 & 3 & 4 & 4 & 2 & 0 & 5.4 & 3 \\
\hline Uruguay & 3 & 1 & . & 2 & 3 & 1 & 41.7 & 6 \\
\hline Venezuela, RB & 4 & 4 & 2 & 1 & 4 & 0 & 14.1 & 4 \\
\hline
\end{tabular}

Note: Except where otherwise indicated, each country was scored 1, 2,3, or 4 for each of the microeconomic variables, with lower values indicating weaker conditions.

a. Scored as follows: 4 indicates forward-looking provisioning criteria, 3 indicates that provisioning is required when loans are 90 days overdue, 2 indicates that provisioning is required when loans are 120 days overdue, and 1 indicates that provisioning is required when loans are 360 days overdue.

b. Based on La Porta, Lopez-de-Silanes, and Shliefer (1998), where thresholds are set at scores of 6 (changed to 1 in this table), 12 (changed to 2 ), and 18 (changed to 3 ).

c. IMF (1998) methodology; see text. 
has a low average value of the microeconomic indicators relative to other countries; otherwise the value is $0 .^{6}$

6 Specifically, each country was scored 1, 2, 3, or 4 for each of the microeconomic variables (with lower values indicating weaker conditions; see table A2). Each country's mean of these scores was then computed and micro set to 1 for countries lower than the median across countries. Thus micro is 1 when microeconomic conditions are weak.
Note that, of the macroeconomic and government control variables, only the real interest rate and change in equity prices were significant in the regressions. The others were then excluded from all reported regressions.

Data on control variables came from the IMF's International Financial Statistics (bank data refers to deposit money banks), the International Finance Corporation's Emerging Markets Database, and La Porta and other (1998) (for enforcement of creditor rights), supplemented by national sources.

\section{References}

Baer, Herbert, and Daniela Klingebiel. 1995. "Systemic Risk When Depositors Bear Losses: Five Case Studies." In G. G. Kaufman, ed., Research in Financial Services: Private and Public Policy. vol. 7. Greenwich, Conn.: JAI Press.

Barth, James R., and Gerard Caprio, and Ross Levine. 2001. "The Regulation and Supervision of Banks around the World: A New Database." Policy Research Working Paper 2588. World Bank, Washington, D.C.

Benston, George J., and G. G. Kaufman. 1995. "Is the Banking and Payments System Fragile?" Journal of Financial Services Research 9: 209-40.

Caprio, Gerard, and Patrick Honohan. 1999. "Restoring Banking Stability: Beyond Supervised Capital Requirements." Journal of Economic Perspectives 13 (4): 43-64.

- 2000. "Reducing the Cost of Banking Crises: Is Basel Enough?" Paper presented at the American Economic Association annual meetings, Boston, Mass.

Caprio, Gerard, and Daniela Klingebiel. 1996. "Bank Insolvencies: Cross-Country Experience.” Policy Research Working Paper 1620. World Bank, Washington, D.C.

1997. "Bank Insolvency: Bad Luck, Bad Policy, or Bad Banking?” In Michael Bruno and Boris Pleskovic, eds., Annual World Bank Conference on Development Economics 1996. Washington, D.C.: World Bank.

Claessens, Stijn. 1999. "Experiences of Resolution of Banking Crises." In Strengthening the Banking System in China. BIS Policy Paper 7. Bank for International Settlements, Basel, Switzerland.

Claessens, Stijn, Simeon Djankov, and Daniela Klingebiel. 2001. "Financial Restructuring in East AsiaHalfway There?" In Stijn Claessens, Simeon Djankov, and Ashoka Mody, eds., Resolution of Financial Distress. Washington, D.C.: World Bank.

Demirgûç-Kunt, Asli, and Enrica Detragiache. 1998. "The Determinants of Banking Crises in Developing and Developed Countries." IMF Staff Paper. International Monetary Fund, Washington, D.C.

1999. "Monitoring Banking Sector Fragility: A Multivariate Logit Approach with an Application to the 1996-97 Banking Crises." The World Bank Economic Review 14 (2): 287-307.

Demirgûç-Kunt, Asli, and Harry Huizinga. 1999. "Market Discipline and Financial Safety Net Design." Policy Research Working Paper 2183. World Bank, Washington, D.C. 
Garcia, Gillian. 1999. "Deposit Insurance-A Survey of Actual and Best Practices." IMF Working Paper 99/ 54. International Monetary Fund, Washington, D.C.

Hoggarth, Glen, Ricardo Reis, and Victoria Saporta. Forthcoming. "Cost of Bank Instability: Some Empirical Evidence." Journal of Banking and Finance.

Honohan, Patrick. 1999. "A Model of Bank Contagion through Lending." International Review of Economics and Finance 8 (2): 147-63.

- 2000. "Banking System Failures in Developing and Transition Countries: Diagnosis and Prediction." Economic Notes 29 (1): 83-109.

Honohan, Patrick, and Daniela Klingebiel. 2000. "Controlling the Fiscal Costs of Banking Crises." Policy Research Working Paper 2441. World Bank, Washington, D.C.

IMF (International Monetary Fund). 1998. World Economic Outlook (May). Washington, D.C.

Kaufman, G. G. 1994. "Bank Contagion: A Review of the Theory and Evidence.” Journal of Financial Services Research 8: 123-50.

Klingebiel, Daniela. 2000. "The Use of Asset Management Companies in the Resolution of Banking Crises-Cross-Country Experience." Policy Research Working Paper 2284. World Bank, Washington, D.C.

La Porta, Rafael, Florencio Lopez-de-Silanes, and Ȧndrei Shleifer. 1998. "Law and Finance.” Journal of Political Economy 106 (6): 13-55.

Lindgren, Carl-Johan, Gillian Garcia, and Matthew I. Saal. 1996. Bank Soundness and Macroeconomic Policy. Washington, D.C.: International Monetary Fund.

McKinnon, Ronald. 1996. The Rules of the Game: International Money and Exchange Rates. Cambridge, Mass.: MIT Press.

Merton, Robert C. 1977. "An Analytic Derivation of the Cost of Deposit Insurance Using Option-Pricing Estimates.” Journal of Banking and Finance 1: 3-11.

Sheng, Andrew, ed. 1996. Bank Restructuring: Lessons from the 1980s. Washington, D.C.: World Bank.

Shleifer, Andrei, and Robert Vishny. 1993. "Corruption.” Quarterly Journal of Economics 108: 599-617. 



\section{Episodes of Systemic and Borderline Banking Crises}

\section{Gerard Caprio and Daniela Klingebiel}

Gerard Caprio is director and Daniela Klingebiel is senior financial economist in the Financial Sector Strategy and Policy Department at the he following table presents information on 113 systemic banking crises (defined as much or all of bank capital being exhausted) that have occurred in 93 countries since the late 1970s. The table also provides information on 50 borderline and smaller (nonsystemic) banking crises in 44 countries during that period. The data are as of 1999. Some judgment has gone into the compilation of this list, not only for countries lacking data on the size of the losses but also for countries where official estimates understate the problem. For instance, at some point in the 1990s nearly every transition economy experienced a banking crisis, but not all of these were included to limit the number of countries with missing information.

Moreover, it is difficult to identify the timeframes of banking insolvencies. Overt crisessuch as those involving a run on banks, on a country's currency, or both - are fairly easy to date, but these are only a subset of the cases listed here. Financial distress, in which the banking system has negative net worth, can occur over a period of time. Indeed, a crisis may persist for some time before
World Bank. The authors are grateful to World Bank staff who provided information for this database.

being detected. The dates attached to the crises reviewed here are those generally accepted by finance experts familiar with the countries, but their accuracy is difficult to determine in the absence of the means to mark portfolios to market values. Similarly, it is not always clear when a crisis is over. In countries that have experienced multiple crises, later events may just be a continuation of earlier events.

As the table shows, the costs of banking crises vary widely. But the data on losses and costs should be treated with caution. Some of the data include corporate restructuring, while others relate only to the restructuring and recapitalization of the financial system. Moreover, we are not able to include the burden borne by depositors and borrowers in the form of wider interest rate spreads resulting from bad loans left on banks' balance sheets. Finally, most of the data on costs do not include costs resulting from indirect methods of bailing out banks. For example, a government may subsidize a borrower by granting it monopoly privilege or other means to improve profits and so repay loans. 


\section{Systemic Banking Crises}

\begin{tabular}{|c|c|c|}
\hline $\begin{array}{l}\text { Sub-Saharan } A \\
\text { Economy }\end{array}$ & $\begin{array}{l}\text { Africa } \\
\text { Scope of crisis }\end{array}$ & Estimated losses or costs \\
\hline $\begin{array}{l}\text { Benin } \\
1988-90\end{array}$ & $\begin{array}{l}\text { All three commercial banks collapsed; } 80 \text { percent of banks' } \\
\text { loan portfolios were nonperforming. }\end{array}$ & $\begin{array}{l}\text { CFA } 95 \text { billion, equivalent to } \\
17 \text { percent of GDP. }\end{array}$ \\
\hline $\begin{array}{l}\text { Burkina Faso } \\
1988-94\end{array}$ & Banking system nonperforming loans estimated at 34 percent. & \\
\hline $\begin{array}{l}\text { Burundi } \\
\text { 1994-? }\end{array}$ & $\begin{array}{l}\text { Banking system nonperforming loans estimated at } 25 \text { percent } \\
\text { in 1995; one bank was liquidated. }\end{array}$ & \\
\hline $\begin{array}{l}\text { Cameroon } \\
1987-93\end{array}$ & $\begin{array}{l}\text { In } 1989 \text { banking system nonperforming loans reached } \\
60-70 \text { percent. Five commercial banks were closed and three } \\
\text { banks were restructured. }\end{array}$ & \\
\hline 1995-98 & $\begin{array}{l}\text { At the end of } 1996 \text { nonperforming loans accounted for } \\
30 \text { percent of total loans. Three banks were restructured and } \\
\text { two were closed. }\end{array}$ & \\
\hline $\begin{array}{l}\text { Cape Verde } \\
\text { 1993-? }\end{array}$ & $\begin{array}{l}\text { At the end of } 1995 \text { commercial banks' nonperforming } \\
\text { loans reached } 30 \text { percent. }\end{array}$ & \\
\hline $\begin{array}{l}\text { Central African Rep. } \\
\text { 1976-92 }\end{array}$ & Four banks were liquidated. & \\
\hline 1988-99 & $\begin{array}{l}\text { The two largest banks, accounting for } 90 \text { percent of assets, } \\
\text { were restructured. Banking system nonperforming loans } \\
\text { reached } 40 \text { percent. }\end{array}$ & \\
\hline $\begin{array}{l}\text { Chad } \\
1980 \text { s }\end{array}$ & Banking sector experienced solvency problems. & \\
\hline 1992 & Nonperforming loans to the private sector reached 35 percent. & \\
\hline
\end{tabular}

Congo, Dem. Rep. of (former Zaire)

1980s Banking sector experienced solvency problems.

1991-92 Four state-owned banks were insolvent; a fifth bank was to be recapitalized with private participation.

1994-present Nonperforming loans to the private sector reached 75 percent. Two state-owned banks have been liquidated and two other state banks privatized. In 1997, 12 banks were having serious financial difficulties.

Congo, Rep. of 1992-present
Two large banks were liquidated. The three remaining banks are insolvent. Situation aggravated by the civil war.

Côte d'Ivoire 1988-91

Four large banks affected, accounting for 90 percent of banking system loans; three definitely and one possibly insolvent. Six government banks closed.
Government costs estimated at CFA 677 billion, equivalent to 25 percent of GDP. 
Systemic Banking Crises

\begin{tabular}{|c|c|c|}
\hline $\begin{array}{l}\text { Suo-sanaran } \\
\text { Economy }\end{array}$ & Scope of crisis & Estimated losses or costs \\
\hline $\begin{array}{l}\text { Equatorial Guinea } \\
\text { 1983-85 }\end{array}$ & Two of the country's largest banks were liquidated. & \\
\hline $\begin{array}{l}\text { Eritrea } \\
1993\end{array}$ & Most of the banking system was insolvent. & \\
\hline $\begin{array}{l}\text { Ghana } \\
1982-89\end{array}$ & $\begin{array}{l}\text { Seven of eleven audited banks insolvent; rural banking } \\
\text { sector affected. }\end{array}$ & $\begin{array}{l}\text { Restructuring costs estimated } \\
\text { at } 6 \text { percent of GNP. }\end{array}$ \\
\hline $\begin{array}{l}\text { Guinea } \\
1985\end{array}$ & $\begin{array}{l}\text { Six banks_accounting for } 99 \text { percent of system } \\
\text { deposits-deemed insolvent. }\end{array}$ & $\begin{array}{l}\text { Repayment of deposits } \\
\text { amounted to } 3 \text { percent of } 1986 \\
\text { GDP. }\end{array}$ \\
\hline 1993-94 & $\begin{array}{l}\text { Two banks deemed insolvent; one other bank had serious } \\
\text { financial difficulties. Together these three banks accounted for } \\
45 \text { percent of the market. }\end{array}$ & \\
\hline $\begin{array}{l}\text { Guinea-Bissau } \\
\text { 1995-? }\end{array}$ & $\begin{array}{l}\text { At the end of } 1995 \text { nonperforming loans accounted for } \\
45 \text { percent of commercial banks' loan portfolio. }\end{array}$ & \\
\hline $\begin{array}{l}\text { Kenya } \\
1985-89\end{array}$ & $\begin{array}{l}\text { Four banks and twenty-four nonbank financial } \\
\text { institutions-accounting for } 15 \text { percent of financial system } \\
\text { liabilities-faced liquidity and solvency problems. }\end{array}$ & \\
\hline 1992 & Intervention in two local banks. & \\
\hline 1993-95 & $\begin{array}{l}\text { Serious solvency problems with banks accounting for more } \\
\text { than } 30 \text { percent of financial system assets. }\end{array}$ & \\
\hline $\begin{array}{l}\text { Liberia } \\
1991-95\end{array}$ & $\begin{array}{l}\text { Seven of eleven banks not operational; in mid- } 1995 \text { their } \\
\text { assets accounted for } 60 \text { percent of bank assets. }\end{array}$ & \\
\hline $\begin{array}{l}\text { Madagascar } \\
1988\end{array}$ & 25 percent of bank loans deemed unrecoverable. & \\
\hline $\begin{array}{l}\text { Mali } \\
1987-89\end{array}$ & Nonperforming loans of largest bank reached 75 percent. & \\
\hline $\begin{array}{l}\text { Mauritania } \\
\text { 1984-93 }\end{array}$ & $\begin{array}{l}\text { In } 1984 \text { five major banks had nonperforming assets ranging } \\
\text { from 45-70 percent of their portfolios. }\end{array}$ & $\begin{array}{l}\text { Cost of rehabilitation estimated } \\
\text { at } 15 \text { percent of GDP in } 1988 .\end{array}$ \\
\hline $\begin{array}{l}\text { Mozambique } \\
\text { 1987-95? }\end{array}$ & $\begin{array}{l}\text { Main commercial bank experienced solvency problems that } \\
\text { became apparent after } 1992 \text {. }\end{array}$ & \\
\hline $\begin{array}{l}\text { Niger } \\
1983-?\end{array}$ & $\begin{array}{l}\text { In the mid-1980s banking system nonperforming loans reached } \\
50 \text { percent. Four banks were liquidated and three restructured } \\
\text { in the late } 1980 \text { s. }\end{array}$ & \\
\hline
\end{tabular}




\section{Systemic Banking Crises}

\begin{tabular}{|c|c|c|}
\hline $\begin{array}{l}\text { Sub-Sahara } \\
\text { Economy }\end{array}$ & $\begin{array}{l}\text { Africa-continued } \\
\text { Scope of crisis }\end{array}$ & Estimated losses or costs \\
\hline $\begin{array}{l}\text { Nigeria } \\
1990 \text { s }\end{array}$ & $\begin{array}{l}\text { In } 1993 \text { insolvent banks accounted for } 20 \text { percent of banking } \\
\text { system assets and } 22 \text { percent of deposits. In } 1995 \text { almost half the } \\
\text { banks reported being in financial distress. }\end{array}$ & \\
\hline $\begin{array}{l}\text { São Tomé and Prir } \\
\text { 1980s-1990s }\end{array}$ & $\begin{array}{l}\text { At the end of 1992, } 90 \text { percent of the monobank's loans were } \\
\text { nonperforming. In } 1993 \text { the commercial and development } \\
\text { departments of the former monobank were liquidated, as was } \\
\text { the only financial institution. At the same time, two new banks } \\
\text { were licensed that took over many of the assets of their } \\
\text { predecessors. The credit operations of one new bank have been } \\
\text { suspended since late } 1994 \text {. }\end{array}$ & \\
\hline $\begin{array}{l}\text { Senegal } \\
1988-91\end{array}$ & $\begin{array}{l}\text { In } 1988,50 \text { percent of banking system loans were } \\
\text { nonperforming. Six commercial banks and one development } \\
\text { bank closed, accounting for } 20-30 \text { percent of financial } \\
\text { system assets. }\end{array}$ & $\begin{array}{l}\$ 830 \text { million, equivalent to } \\
17 \text { percent of GDP. }\end{array}$ \\
\hline $\begin{array}{l}\text { Sierra Leone } \\
\text { 1990-present }\end{array}$ & $\begin{array}{l}\text { In 1995, 40-50 percent of banking system loans were } \\
\text { nonperforming. One bank's license was suspended in } 1994 . \\
\text { Bank recapitalization and restructuring are ongoing. }\end{array}$ & \\
\hline $\begin{array}{l}\text { Swaziland } \\
1995\end{array}$ & $\begin{array}{l}\text { Meridien BIAO Swaziland was taken over by the Central Bank. } \\
\text { The Central Bank also took over the Swaziland Development } \\
\text { and Savings Bank, which faced severe portfolio problems. }\end{array}$ & \\
\hline $\begin{array}{l}\text { Tanzania } \\
\text { Late 1980s; 1990s }\end{array}$ & $\begin{array}{l}\text { In } 1987 \text { the main financial institutions had arrears amounting to } \\
\text { half their portfolios. In } 1995 \text { it was determined that the National } \\
\text { Bank of Commerce, which accounted for } 95 \text { percent of banking } \\
\text { system assets, had been insolvent since at least } 1990 \text {. }\end{array}$ & $\begin{array}{l}\text { In } 1987 \text { implied losses } \\
\text { amounted to nearly } 10 \text { percent } \\
\text { of GNP. }\end{array}$ \\
\hline $\begin{array}{l}\text { Togo } \\
\text { 1993-95. }\end{array}$ & Banking sector experienced solvency problems. & \\
\hline $\begin{array}{l}\text { Uganda } \\
\text { 1994-present }\end{array}$ & Half of banking system facing solvency problems. & \\
\hline $\begin{array}{l}\text { Zambia } \\
1995\end{array}$ & $\begin{array}{l}\text { Meridian Bank, which accounted for } 13 \text { percent of commercial } \\
\text { bank assets, became insolvent. }\end{array}$ & $\begin{array}{l}\$ 50 \text { million ( } 1.4 \text { percent } \\
\text { of GDP). }\end{array}$ \\
\hline $\begin{array}{l}\text { Zimbabwe } \\
\text { 1995-present }\end{array}$ & five commercial banks have high nonperforming loans. & \\
\hline
\end{tabular}




\section{Systemic Banking Crises}

\begin{tabular}{|c|c|c|}
\hline \multicolumn{3}{|c|}{ East and South Asia } \\
\hline $\begin{array}{l}\text { Bangladesh } \\
\text { Late 1980s-96 }\end{array}$ & $\begin{array}{l}\text { In } 1987 \text { four banks accounting for } 70 \text { percent of credit had } \\
\text { nonperforming loans of } 20 \text { percent. From the late } 1980 \text { s the entire } \\
\text { private and public banking system was technically insolvent. }\end{array}$ & \\
\hline $\begin{array}{l}\text { China } \\
1990 \text { s }\end{array}$ & $\begin{array}{l}\text { At the end of } 1998 \text { China's four large state-owned commercial } \\
\text { banks, accounting for } 68 \text { percent of banking system assets, } \\
\text { were deemed insolvent. Banking system nonperforming loans } \\
\text { were estimated at } 50 \text { percent. }\end{array}$ & $\begin{array}{l}\text { Net losses estimated to reach } \\
\$ 428 \text { billion, or } 47 \text { percent of } \\
\text { GDP in } 1999 \text {. }\end{array}$ \\
\hline $\begin{array}{l}\text { Indonesia } \\
\text { 1997-present }\end{array}$ & $\begin{array}{l}\text { By March } 1999 \text { Bank Indonesia had closed } 61 \text { banks and } \\
\text { nationalized 54, of a total of } 240 \text {. Nonperforming loans for the } \\
\text { banking system estimated at } 65-75 \text { percent of total loans. }\end{array}$ & $\begin{array}{l}\text { Fiscal costs estimated at } \\
50-55 \text { percent of GDP. }\end{array}$ \\
\hline $\begin{array}{l}\text { Korea, Rep. of } \\
\text { 1997-present }\end{array}$ & $\begin{array}{l}\text { In March 1999, } 2 \text { of } 26 \text { commercial banks-accounting for } \\
12 \text { percent of banking system assets-were nationalized. Five } \\
\text { banks-accounting for } 8 \text { percent of banking system assets- } \\
\text { were closed. Seven banks-accounting for } 38 \text { percent of } \\
\text { banking system assets-were placed under special supervision. } \\
\text { Banking system nonperforming loans are expected to peak at } \\
30-40 \text { percent. }\end{array}$ & $\begin{array}{l}\text { Net losses estimated at } \\
\$ 68 \text { billion, or } 20 \text { percent of } \\
\text { GDP in } 1999 .\end{array}$ \\
\hline $\begin{array}{l}\text { Malaysia } \\
\text { 1997-present }\end{array}$ & $\begin{array}{l}\text { Finance companies are being restructured, and the number of } \\
\text { finance companies is to be reduced from } 39 \text { to } 16 \text { through } \\
\text { mergers. Two finance companies were taken over by the } \\
\text { Central Bank, including the largest independent finance } \\
\text { company. Two banks deemed insolvent-accounting for } \\
14 \text { percent of financial system assets-will be merged with other } \\
\text { banks. At the end of } 1998 \text { nonperforming loans estimated at } \\
25-35 \text { percent of banking system assets. }\end{array}$ & $\begin{array}{l}\text { Net losses estimated at } \\
\text { \$15 billion, or } 21 \text { percent of } \\
\text { GDP in } 1999 .\end{array}$ \\
\hline $\begin{array}{l}\text { Nepal } \\
1988\end{array}$ & $\begin{array}{l}\text { In early } 1988 \text { the reported arrears of three banks accounting for } \\
95 \text { percent of the financial system averaged } 29 \text { percent of assets. }\end{array}$ & \\
\hline $\begin{array}{l}\text { Philippines } \\
\text { 1981-87 }\end{array}$ & $\begin{array}{l}\text { Problems in two public banks accounting for } 50 \text { percent of } \\
\text { banking system assets, six private banks accounting for } \\
12 \text { percent of banking system assets, } 32 \text { thrifts accounting for } \\
53 \text { percent of thrift banking assets, and } 128 \text { rural banks. }\end{array}$ & $\begin{array}{l}\text { At its peak, central bank } \\
\text { assistance to financial } \\
\text { institutions amounted to } \\
19 \text { billion pesos ( } 3 \text { percent of } \\
\text { GDP). }\end{array}$ \\
\hline 1998-present & $\begin{array}{l}\text { Since January } 1998 \text { one commercial bank, } 7 \text { of } 88 \text { thrifts, and } \\
40 \text { of } 750 \text { rural banks have been placed under receivership. } \\
\text { Banking system nonperforming loans reached } 12 \text { percent by } \\
\text { November 1998, and were expected to reach } 20 \text { percent in } 1999 .\end{array}$ & $\begin{array}{l}\text { Net losses estimated at } \\
\$ 4 \text { billion, or } 7 \text { percent of } \\
\text { GDP in } 1999 \text {. }\end{array}$ \\
\hline
\end{tabular}




\section{Systemic Banking Crises}

\begin{tabular}{|c|c|c|}
\hline \multicolumn{2}{|c|}{ East and South Asia-continued } & Estimated losses or costs \\
\hline $\begin{array}{l}\text { Sri Lanka } \\
1989-93\end{array}$ & $\begin{array}{l}\text { State-owned banks comprising } 70 \text { percent of banking system } \\
\text { estimated to have nonperforming loans of about } 35 \text { percent. }\end{array}$ & $\begin{array}{l}\text { Restructuring cost amounted } \\
\text { to } 25 \text { billion rupees ( } 5 \text { percent } \\
\text { of GDP). }\end{array}$ \\
\hline $\begin{array}{l}\text { Taiwan, China } \\
\text { 1997-98 }\end{array}$ & $\begin{array}{l}\text { Banking system nonperforming loans estimated at } 15 \text { percent at } \\
\text { the end of } 1998 .\end{array}$ & $\begin{array}{l}\text { In } 1999 \text { net losses estimated } \\
\text { at } \$ 26.7 \text { billion, or } 11.5 \text { percent } \\
\text { of GDP. }\end{array}$ \\
\hline $\begin{array}{l}\text { Thailand } \\
\text { 1983-87 }\end{array}$ & $\begin{array}{l}\text { Authorities intervened in } 50 \text { finance and security firms and } \\
5 \text { commercial banks, or about } 25 \text { percent of financial system } \\
\text { assets; } 3 \text { commercial banks deemed insolvent (accounting for } \\
14 \text { percent of commercial bank assets). }\end{array}$ & $\begin{array}{l}\text { Government cost for } 50 \\
\text { finance companies estimated } \\
\text { at } 0.5 \text { percent of GNP; } \\
\text { government cost for } \\
\text { subsidized loans amounted to } \\
\text { about } 0.2 \text { percent of GDP } \\
\text { a year. }\end{array}$ \\
\hline 1997-present & $\begin{array}{l}\text { Through March } 1999 \text { the Bank of Thailand intervened in } 70 \text { (of } \\
91 \text { ) finance companies that together accounted for } 13 \text { percent of } \\
\text { financial system assets and } 72 \text { percent of finance company } \\
\text { assets. It also intervened in six banks that together had a market } \\
\text { share of } 12 \text { percent. At the end of } 1998 \text { banking system } \\
\text { nonperforming loans reached } 46 \text { percent. }\end{array}$ & $\begin{array}{l}\text { Net losses estimated at } \\
\$ 60 \text { billion, or } 42 \text { percent of } \\
\text { GDP in } 1999 .\end{array}$ \\
\hline $\begin{array}{l}\text { Vietnam } \\
\text { 1997-present }\end{array}$ & $\begin{array}{l}\text { Two of four large state-owned commercial banks-accounting } \\
\text { for } 51 \text { percent of banking system loans-deemed insolvent; the } \\
\text { other two are experiencing significant solvency problems. Several } \\
\text { joint stock banks are in severe financial distress. Banking system } \\
\text { nonperforming loans reached } 18 \text { percent in late } 1998 \text {. }\end{array}$ & \\
\hline $\begin{array}{l}\text { Latin Ame } \\
\text { Economy }\end{array}$ & $\begin{array}{l}\text { and the Caribbean } \\
\text { Scope of crisis }\end{array}$ & Estimated losses or costs \\
\hline $\begin{array}{l}\text { Argentina } \\
1980-82\end{array}$ & $\begin{array}{l}\text { More than } 70 \text { institutions-accounting for } 16 \text { percent of } \\
\text { commercial bank assets and } 35 \text { percent of finance company } \\
\text { assets-were liquidated or subjected to central bank intervention. }\end{array}$ & 55 percent of GDP. \\
\hline 1989-90 & $\begin{array}{l}\text { Nonperforming assets accounted for } 27 \text { percent of the aggregate } \\
\text { portfolio and } 37 \text { percent of the portfolios of state banks. Failed } \\
\text { banks held } 40 \text { percent of financial system assets. }\end{array}$ & \\
\hline 1995 & $\begin{array}{l}\text { Eight banks suspended and three banks collapsed. Through the } \\
\text { end of } 1997,63 \text { of } 205 \text { banking institutions were closed or } \\
\text { merged. }\end{array}$ & $\begin{array}{l}\text { Direct and indirect costs to } \\
\text { public estimated at } 2 \text { percent } \\
\text { of GDP. }\end{array}$ \\
\hline
\end{tabular}


Systemic Banking Crises

\begin{tabular}{|c|c|c|}
\hline Economy & Scope of crisis & Estimated losses or costs \\
\hline \multicolumn{3}{|l|}{ Bolivia } \\
\hline $1986-88$ & $\begin{array}{l}\text { Five banks were liquidated. Banking system nonperforming } \\
\text { loans reached } 30 \text { percent in } 1987 \text {; in mid- } 1988 \text { reported arrears } \\
\text { stood at } 92 \text { percent of commercial banks' net worth. }\end{array}$ & \\
\hline 1994-? & $\begin{array}{l}\text { Two banks with } 11 \text { percent of banking system assets were closed } \\
\text { in 1994. In 1995, } 4 \text { of } 15 \text { domestic banks, accounting for } \\
30 \text { percent of banking system assets, experienced liquidity } \\
\text { problems and suffered high nonperforming loans. }\end{array}$ & \\
\hline \multicolumn{3}{|l|}{ Brazil } \\
\hline 1990 & Deposits converted to bonds. & \\
\hline 1994-present & $\begin{array}{l}\text { By the end of } 1997 \text { the Central Bank had intervened in or put } \\
\text { under temporary administration } 43 \text { financial institutions, and } \\
\text { banking system nonperforming loans reached } 15 \text { percent. }\end{array}$ & $\begin{array}{l}\text { In } 1996 \text { the negative net worth } \\
\text { of selected state and federal } \\
\text { banks was } 5-10 \text { percent of } \\
\text { GDP. By the end of } 1997 \text { bank } \\
\text { recapitalizations had cost } \$ 3 \\
\text { billion for Banco Economico, } \\
\$ 3 \text { billion for Bamerindus, } \\
\$ 8 \text { billion for Banco do Brazil, } \\
\text { and } \$ 5 \text { billion for Unibanco. In } \\
1998 \text { public support to private } \\
\text { banks cost } 1-2 \text { percent of } \\
\text { GDP. }\end{array}$ \\
\hline \multicolumn{3}{|l|}{ Chile } \\
\hline 1976 & Entire mortgage system insolvent. & \\
\hline $1981-83$ & $\begin{array}{l}\text { In } 1981 \text { the authorities intervened in four banks and four } \\
\text { nonbank financial institutions accounting for } 33 \text { percent of } \\
\text { outstanding loans. In } 1983 \text { the authorities intervened in seven } \\
\text { banks and one financiera accounting for } 45 \text { percent of financial } \\
\text { system assets. By the end of } 1983,19 \text { percent of loans were } \\
\text { nonperforming. }\end{array}$ & $\begin{array}{l}\text { In } 1982-85 \text { the government } \\
\text { spent } 42 \text { percent of GDP to } \\
\text { resolve the banking crisis. }\end{array}$ \\
\hline \multicolumn{3}{|l|}{ Colombia } \\
\hline $1982-87$ & $\begin{array}{l}\text { The Central Bank intervened in six banks accounting for } \\
25 \text { percent of banking system assets. }\end{array}$ & $\begin{array}{l}\text { Restructuring costs were } \\
\text { estimated to be about } 5 \\
\text { percent of GDP. }\end{array}$ \\
\hline \multicolumn{3}{|l|}{ Costa Rica } \\
\hline Several instances & $\begin{array}{l}\text { In } 1987 \text { public banks accounting for } 90 \text { percent of banking } \\
\text { system loans were in financial distress, with } 32 \text { percent of their } \\
\text { loans considered uncollectable. }\end{array}$ & $\begin{array}{l}\text { Implied losses of at least twice } \\
\text { the capital plus reserves. }\end{array}$ \\
\hline
\end{tabular}




\section{Systemic Banking Crises}

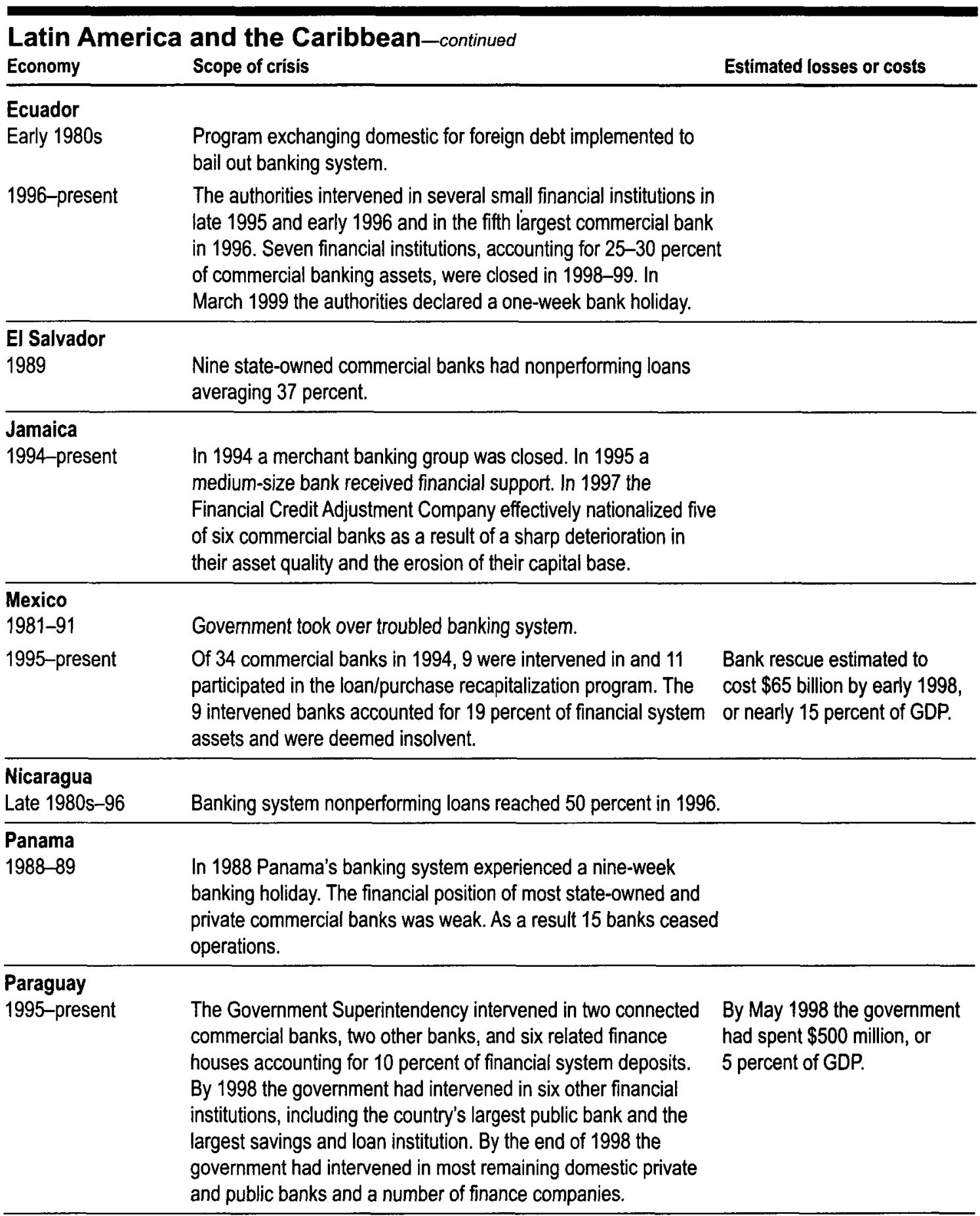


Systemic Banking Crises

\begin{tabular}{|c|c|c|}
\hline Economy & Scope of crisis & Estimated losses or costs \\
\hline \multicolumn{3}{|c|}{$\begin{array}{l}\text { Two large banks failed. The rest of the system suffered from high } \\
\text { nonperforming loans and financial disintermediation following the } \\
\text { nationalization of the banking system in } 1987 \text {. }\end{array}$} \\
\hline \multicolumn{3}{|l|}{ Uruguay } \\
\hline $1981-84$ & $\begin{array}{l}\text { Affected institutions accounted for } 30 \text { percent of financial system } \\
\text { assets; insolvent banks accounted for } 20 \text { percent of financial } \\
\text { system deposits. }\end{array}$ & $\begin{array}{l}\text { The costs of recapitalizing } \\
\text { banks were estimated at } \\
\$ 350 \text { million, or } 7 \text { percent of } \\
\text { GNP. In } 1982-85 \text { the Central } \\
\text { Bank's quasi-fiscal losses } \\
\text { associated with subsidized } \\
\text { credit operations and loan } \\
\text { portfolio purchases amounted } \\
\text { to } 24 \text { percent of GDP. }\end{array}$ \\
\hline
\end{tabular}

Venezuela, RB 1994-present
Insolvent banks accounted for 30 percent of financial system deposits in 1994. In 1994 the authorities intervened in 13 of 47 banks that held 50 percent of deposits, and in 1995 in five additional banks.
Losses were estimated at more than 18 percent of GDP.

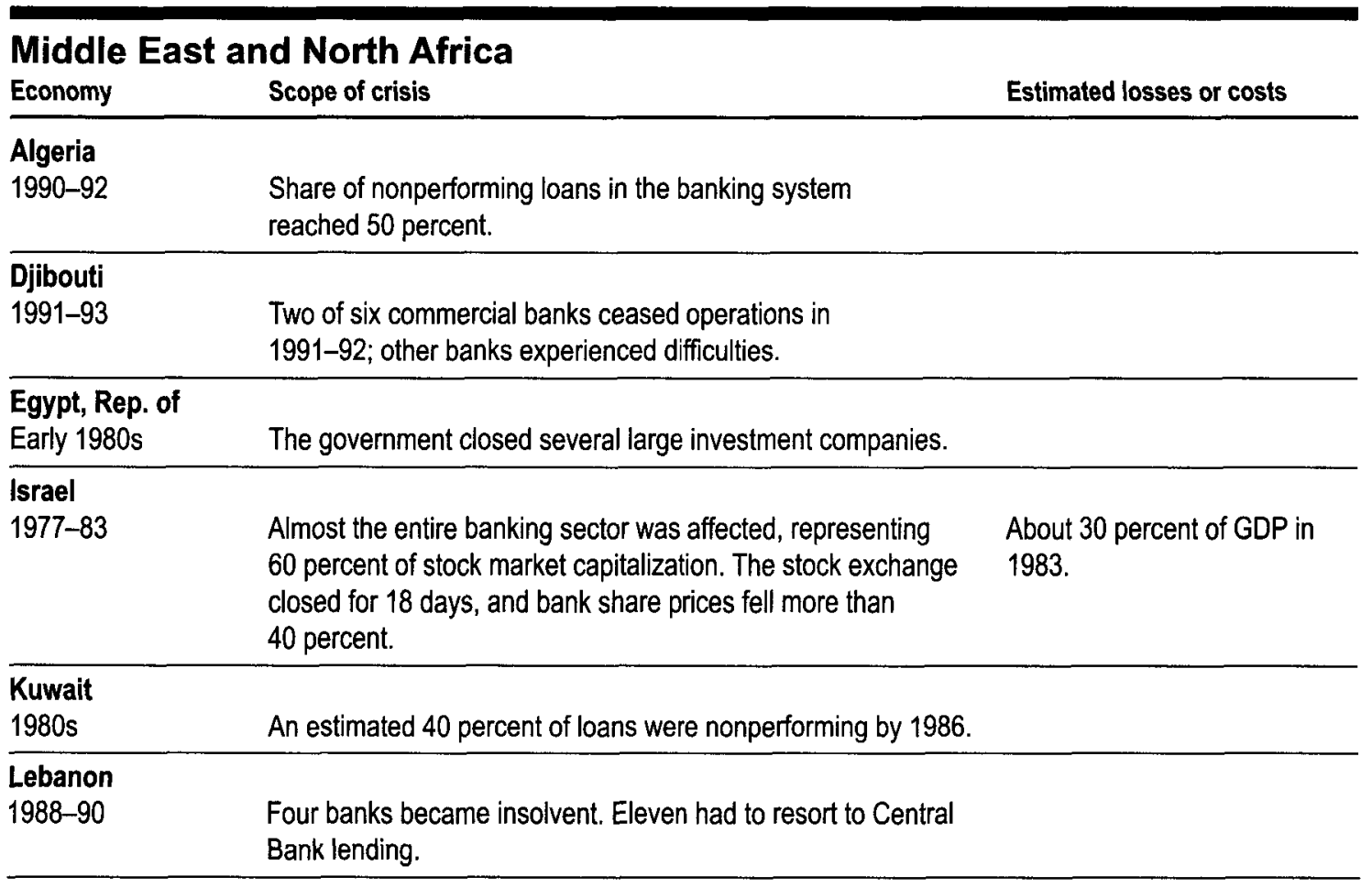




\section{Systemic Banking Crises}

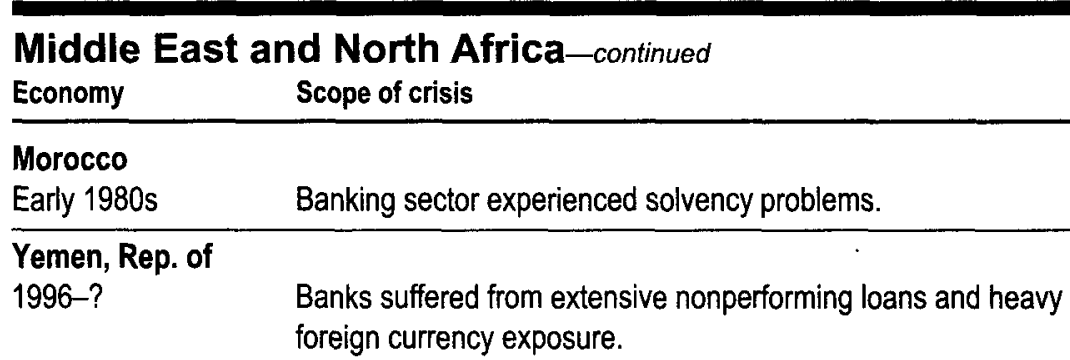

\section{Europe and Central Asia}

Scope of crisis

Turkey

$1982-85$

Three banks were merged with the state-owned Agriculture

Rescue costs totaled

Bank and then liquidated; two large banks were restructured. 2.5 percent of GNP.

\section{Transition economies}

Economy

Scope of crisis

Albania

1992-?

After the July 1992 cleanup, 31 percent of "new" banking system loans were nonperforming. Some banks faced liquidity problems due to a logjam of interbank liabilities.

\begin{tabular}{|c|c|c|}
\hline $\begin{array}{l}\text { Armenia } \\
\text { 1994-96 }\end{array}$ & $\begin{array}{l}\text { Starting in August 1994, the Central Bank closed half of active } \\
\text { banks. Large banks continued to suffer from high nonperforming } \\
\text { loans. The savings bank was financially weak. }\end{array}$ & \\
\hline $\begin{array}{l}\text { Azerbaijan } \\
\text { 1995-? }\end{array}$ & $\begin{array}{l}\text { Twelve private banks closed; three large state-owned banks } \\
\text { deemed insolvent; one large state-owned bank faced serious } \\
\text { liquidity problems. }\end{array}$ & \\
\hline $\begin{array}{l}\text { Bosnia and } \mathrm{He} \\
\text { 1992-present }\end{array}$ & $\begin{array}{l}\text { vina } \\
\text { Banking system suffers from high nonperforming loans due to the } \\
\text { breakup of the former Yugoslavia and the civil war. }\end{array}$ & \\
\hline $\begin{array}{l}\text { Bulgaria } \\
1990 \text { s }\end{array}$ & $\begin{array}{l}\text { In } 1995 \text { an estimated } 75 \text { percent of banking system loans were } \\
\text { substandard. The banking system experienced a run in early } \\
\text { 1996. The government then stopped providing bailouts, } \\
\text { prompting the closure of } 19 \text { banks accounting for one-third of } \\
\text { sector assets. Surviving banks were recapitalized by } 1997 \text {. }\end{array}$ & $\begin{array}{l}\text { By early } 1996 \text { the sector had a } \\
\text { negative net worth equal to } \\
3 \text { percent of GDP. }\end{array}$ \\
\hline $\begin{array}{l}\text { Croatia } \\
1996\end{array}$ & $\begin{array}{l}\text { Five banks accounting for about half of banking system loans } \\
\text { were deemed insolvent and taken over by the Bank Rehabilitation } \\
\text { Agency. }\end{array}$ & \\
\hline
\end{tabular}




\section{Systemic Banking Crises}

\begin{tabular}{lll}
$\begin{array}{l}\text { Transition economies-continued } \\
\text { Economy }\end{array}$ & Scope of crisis & Estimated losses or costs \\
\hline $\begin{array}{l}\text { Czech Republic } \\
1991-?\end{array}$ & $\begin{array}{l}\text { Several banks have closed since 1993. In 1994-95, 38 percent } \\
\text { of banking system loans were nonperforming. }\end{array}$ & $\begin{array}{l}\text { Through 1994, 12 percent of } \\
\text { GDP was spent on bank } \\
\text { support. }\end{array}$ \\
\hline
\end{tabular}

\section{Estonia}

1992-95

Insolvent banks accounted for 41 percent of financial system assets. Five banks' licenses were revoked, and two major bankswere merged and nationalized. Two other large banks were merged and converted to a loan recovery agency. In 1994 the Social Bank, which controlled 10 percent of financial system assets, failed.
Recapitalization outlays for new entity totaled 300 million kroon, or 1.4 percent of $1993 \mathrm{GDP}$.

Most large banks virtually insolvent. About one-third of banking system loans were nonperforming.

\begin{tabular}{lll}
\hline $\begin{array}{l}\text { Georgia } \\
1991-?\end{array}$ & $\begin{array}{l}\text { Most large banks virtually insolvent. About one-third of banking } \\
\text { system loans were nonperforming. }\end{array}$ \\
\hline $\begin{array}{l}\text { Hungary } \\
1991-95\end{array}$ & $\begin{array}{l}\text { In the second half of } 1993 \text { eight banks-accounting for } \\
25 \text { percent of financial system assets-were deemed insolvent. }\end{array}$ & $\begin{array}{l}\text { Resolution costs estimated } \\
\text { to total 10 percent of GDP. }\end{array}$ \\
\hline $\begin{array}{l}\text { Kyrgyz Republic } \\
1990 \text { s }\end{array}$ & $\begin{array}{l}\text { Some } 80-90 \text { percent of banking system loans doubtful. Four } \\
\text { small commercial banks closed in 1995. }\end{array}$ & \\
\hline $\begin{array}{l}\text { Latvia } \\
1995-\text { present }\end{array}$ & $\begin{array}{l}\text { Between } 1994 \text { and 1999, 35 banks saw their license revoked, } \\
\text { were closed, or ceased operations. }\end{array}$ & $\begin{array}{l}\text { In 1995 the negative net worth } \\
\text { of the banking system was } \\
\text { estimated at \$320 million, or } \\
\end{array}$ \\
& & $\begin{array}{l}7 \text { percent of GDP. Aggregate } \\
\text { banking system losses in 1998 } \\
\text { estimated at 100 million lats } \\
\text { (\$172 million), about } 3 \text { percent } \\
\text { of GDP. }\end{array}$
\end{tabular}

Lithuania

1995-96 In 1995, of 25 banks, 12 small banks were liquidated, 3 private banks (accounting for 29 percent of banking system deposits) failed, and 3 state-owned banks were deemed insolvent.

Macedonia, FYR 1993-94

About 70 percent of banking system loans were nonperforming. The government took over banks' foreign debt and closed the second largest bank.
Costs of banking system rehabilitation, obligations from assumption of external debt, liabilities regarding frozen foreign exchange, and contingent liabilities in banks together estimated at 32 percent of GDP. 


\section{Systemic Banking Crises}

\begin{tabular}{|c|c|c|}
\hline $\begin{array}{l}\text { Trans } \\
\text { Economy }\end{array}$ & $\begin{array}{l}\text { nomies_continued } \\
\text { Scope of crisis }\end{array}$ & Estimated losses or costs \\
\hline \multicolumn{3}{|l|}{ Poland } \\
\hline $1990 \mathrm{~s}$ & $\begin{array}{l}\text { In } 1991 \text { seven of nine treasury-owned commercial banks- } \\
\text { accounting for } 90 \text { percent of credit-the Bank for Food Economy, } \\
\text { and the cooperative banking sector experienced solvency } \\
\text { problems. }\end{array}$ & $\begin{array}{l}\text { In } 1993 \text { recapitalization costs } \\
\text { were } \$ 750 \text { million for the } \\
\text { seven commercial banks and } \\
\$ 900 \text { million for the Bank for } \\
\text { Food Economy and the } \\
\text { cooperative banking sector, for } \\
\text { a total equivalent to } 2 \text { percent } \\
\text { of GDP. }\end{array}$ \\
\hline
\end{tabular}

Romania 1990-present 1998 nonperforming loans reached $25-30$ percent in the six
main state-owned banks.

The Agricultural Bank was recapitalized on a flow basis. In 1998 the Central Bank injected $\$ 210$ million (0.6 percent of GDP) in Bancorex, the largest state bank, and in 1999 another $\$ 60$ million.

\begin{tabular}{|c|c|c|}
\hline $\begin{array}{l}\text { Russian Federation } \\
1995\end{array}$ & $\begin{array}{l}\text { In August } 1995 \text { the interbank loan market stopped working due to } \\
\text { concerns about connected lending in many new banks. }\end{array}$ & \\
\hline 1998-99 & $\begin{array}{l}\text { Nearly } 720 \text { banks, or half of those now operating, were deemed } \\
\text { insolvent. These banks accounted for } 4 \text { percent of sector assets } \\
\text { and } 32 \text { percent of retail deposits. According to the Central Bank, } \\
18 \text { banks holding } 40 \text { percent of sector assets and } 41 \text { percent of } \\
\text { household deposits are in serious difficulties and will require } \\
\text { rescue by the state. }\end{array}$ & $\begin{array}{l}\text { In } 1999 \text { bailout costs were } \\
\text { estimated at } \$ 15 \text { billion, } \\
\text { or 5-7 percent of GDP. }\end{array}$ \\
\hline $\begin{array}{l}\text { Slovak Republic } \\
\text { 1991-present }\end{array}$ & $\begin{array}{l}\text { In } 1997 \text { unrecoverable loans were estimated at } 101 \text { billion crowns, } \\
\text { or about } 31 \text { percent of loans and } 15 \text { percent of GDP. }\end{array}$ & \\
\hline $\begin{array}{l}\text { Slovenia } \\
1992-94\end{array}$ & $\begin{array}{l}\text { Three banks-accounting for two-thirds of banking system } \\
\text { assets-were restructured. }\end{array}$ & $\begin{array}{l}\text { Recapitalizations cost } \$ 1.3 \\
\text { billion. }\end{array}$ \\
\hline $\begin{array}{l}\text { Ukraine } \\
1997-98\end{array}$ & $\begin{array}{l}\text { By } 1997,32 \text { of } 195 \text { banks were being liquidated, while } 25 \text { others } \\
\text { were undergoing financial rehabilitation. Bad loans accounted for } \\
50-65 \text { percent of assets even in some leading banks. In } 1998 \\
\text { banks were further hit by the government's decision to restructure } \\
\text { government debt. }\end{array}$ & \\
\hline
\end{tabular}




\section{Systemic Banking Crises}

\begin{tabular}{|c|c|c|}
\hline \multicolumn{2}{|c|}{$\begin{array}{l}\text { Industrial countries } \\
\text { Economy } \quad \text { Scope of crisis }\end{array}$} & Estimated losses or costs \\
\hline $\begin{array}{l}\text { Finland } \\
1991-94\end{array}$ & $\begin{array}{l}\text { Savings banks badly affected; government took control of } \\
\text { three banks that together accounted for } 31 \text { percent of system } \\
\text { deposits. }\end{array}$ & $\begin{array}{l}\text { Recapitalization costs } \\
\text { amounted to } 11 \text { percent of } \\
\text { GDP. }\end{array}$ \\
\hline $\begin{array}{l}\text { Japan } \\
\text { 1990s }\end{array}$ & $\begin{array}{l}\text { Banks suffered from sharp decline in stock market and real } \\
\text { estate prices. In } 1995 \text { the official estimate of nonperforming } \\
\text { loans was } 40 \text { trillion yen ( } \$ 469 \text { billion, or } 10 \text { percent of GDP). } \\
\text { An unofficial estimate put nonperforming loans at } \$ 1 \text { trillion, } \\
\text { equivalent to } 25 \text { percent of GDP. Banks made provisions for } \\
\text { some bad loans. At the end of } 1998 \text { banking system } \\
\text { nonperforming loans were estimated at } 88 \text { trillion yen } \\
\text { (\$725 billion, or } 18 \text { percent of GDP). In } 1999 \text { Hakkaido } \\
\text { Takushodu bank was closed, the Long Term Credit Bank was } \\
\text { nationalized, Yatsuda Trust was merged with Fuji Bank, and } \\
\text { Mitsui Trust was merged with Chuo Trust. }\end{array}$ & $\begin{array}{l}\text { In } 1996 \text { rescue costs were } \\
\text { estimated at more than } \\
\$ 100 \text { billion. In } 1998 \text { the } \\
\text { government announced the } \\
\text { Obuchi Plan, which provided } \\
60 \text { trillion yen ( } \$ 500 \text { billion, } \\
\text { or } 12 \text { percent of GDP) in } \\
\text { public funds for loan losses, } \\
\text { bank recapitalizations, and } \\
\text { depositor protection. }\end{array}$ \\
\hline $\begin{array}{l}\text { Norway } \\
1987-93\end{array}$ & $\begin{array}{l}\text { The Central Bank provided special loans to six banks suffering } \\
\text { from the recession of } 1985-86 \text { and from problem real estate } \\
\text { loans. The state took control of the three largest banks (with } \\
85 \text { percent of banking system assets, whose loan losses had } \\
\text { wiped out capital), partly through a Government Bank Investment } \\
\text { Fund ( } 5 \text { billion kroner), and the state-backed Bank Insurance } \\
\text { Fund had to increase capital to } 11 \text { billion kroner. }\end{array}$ & $\begin{array}{l}\text { Recapitalization costs totaled } \\
8 \text { percent of GDP. }\end{array}$ \\
\hline $\begin{array}{l}\text { Spain } \\
1977-85\end{array}$ & $\begin{array}{l}\text { In 1978-83, } 24 \text { institutions were rescued, } 4 \text { were liquidated, } \\
4 \text { were merged, and } 20 \text { small and medium-size banks were } \\
\text { nationalized. These } 52 \text { banks (of 110), representing } 20 \text { percent } \\
\text { of banking system deposits, were experiencing solvency problem }\end{array}$ & $\begin{array}{l}\text { Estimated bank losses were } \\
\text { equivalent to about } 17 \text { percent } \\
\text { of GNP. } \\
\text { Is. }\end{array}$ \\
\hline $\begin{array}{l}\text { Sweden } \\
1991-94\end{array}$ & $\begin{array}{l}\text { Nordbanken and Gota Bank, accounting for } 22 \text { percent of } \\
\text { banking system assets, were insolvent. Sparbanken Foresta, } \\
\text { accounting for } 24 \text { percent of banking system assets, intervened. } \\
\text { Overall, five of the six largest banks, accounting for more than } \\
70 \text { percent of banking system assets, experienced difficulties. }\end{array}$ & $\begin{array}{l}\text { Recapitalization costs totaled } \\
4 \text { percent of GDP. }\end{array}$ \\
\hline
\end{tabular}




\section{Borderline and Smaller (Nonsystemic) Banking Crises}

\begin{tabular}{|c|c|c|}
\hline \multicolumn{3}{|c|}{ Sub-Saharan Africa } \\
\hline $\begin{array}{l}\text { Angola } \\
\text { 1991-present }\end{array}$ & $\begin{array}{l}\text { Two state-owned commercial banks have experienced } \\
\text { solvency problems. }\end{array}$ & \\
\hline $\begin{array}{l}\text { Botswana } \\
1994-95\end{array}$ & $\begin{array}{l}\text { One problem bank was merged in 1994, a small bank was } \\
\text { liquidated in 1995, and the state-owned National Development } \\
\text { Bank was recapitalized. }\end{array}$ & $\begin{array}{l}\text { Recapitalizing the National } \\
\text { Development Bank cost } \\
0.6 \text { percent of GDP. }\end{array}$ \\
\hline $\begin{array}{l}\text { Ethiopia } \\
\text { 1994-95 }\end{array}$ & $\begin{array}{l}\text { A government-owned bank was restructured, and its } \\
\text { nonperforming loans were taken over by the government. }\end{array}$ & \\
\hline $\begin{array}{l}\text { Gabon } \\
1995-?\end{array}$ & One bank was temporarily closed in 1995. & \\
\hline $\begin{array}{l}\text { Gambia, The } \\
1985-92\end{array}$ & In 1992 a government bank was restructured and privatized. & \\
\hline $\begin{array}{l}\text { Ghana } \\
\text { 1997-present }\end{array}$ & $\begin{array}{l}\text { Nonperforming loans increased sharply in } 1997 \text {, from } 16 \text { percent } \\
\text { to } 27 \text { percent. Two state-owned commercial banks-accounting } \\
\text { for } 34 \text { percent of the market-are in bad shape. Three banks, } \\
\text { accounting for } 4 \text { percent of deposits, are insolvent. }\end{array}$ & \\
\hline $\begin{array}{l}\text { Kenya } \\
1996-?\end{array}$ & At the end of 1996 nonperforming loans reached 19 percent. & \\
\hline $\begin{array}{l}\text { Lesotho } \\
1988-?\end{array}$ & $\begin{array}{l}\text { One of four commercial banks suffered from large nonperforming } \\
\text { loans. }\end{array}$ & \\
\hline $\begin{array}{l}\text { Mauritius } \\
1996\end{array}$ & $\begin{array}{l}\text { The Central Bank closed } 2 \text { of } 12 \text { commercial banks for fraud and } \\
\text { other irregularities. }\end{array}$ & \\
\hline $\begin{array}{l}\text { Nigeria } \\
1997\end{array}$ & Distressed banks accounted for 4 percent of banking system asset & \\
\hline $\begin{array}{l}\text { Rwanda } \\
1991-?\end{array}$ & One bank, with a well-established network, closed. & \\
\hline $\begin{array}{l}\text { South Africa } \\
1977 \\
1989-?\end{array}$ & $\begin{array}{l}\text { Trust Bank experienced problems } \\
\text { Some banks are experiencing problems. }\end{array}$ & \\
\hline
\end{tabular}


Borderline and Smaller (Nonsystemic) Banking Crises

\begin{tabular}{|c|c|c|}
\hline Economy & Scope of crisis & Estimated losses or costs \\
\hline \multicolumn{3}{|l|}{ Tunisia } \\
\hline 1991-95 & In 1991 most commercial banks were undercapitalized. & $\begin{array}{l}\text { During } 1991-94 \text { the banking } \\
\text { system raised equity } \\
\text { equivalent to } 1.5 \text { percent of } \\
\text { GDP and made provisions } \\
\text { equivalent to another } \\
1.5 \text { percent. Thus } \\
\text { recapitalization through } 1994 \\
\text { required at least } 3 \text { percent of } \\
\text { GDP. }\end{array}$ \\
\hline
\end{tabular}

\section{East and South Asia}

Economy

Scope of crisis

Estimated losses or costs

Brunei

Mid-1980s-1990s Several financial firms failed. The second largest bank failed in

1986. In 1991, 9 percent of loans were past due.

\begin{tabular}{|c|c|c|}
\hline $\begin{array}{l}\text { Hong Kong, China } \\
\text { 1982-83 }\end{array}$ & Nine deposit-taking companies failed. & \\
\hline $1983-86$ & $\begin{array}{l}\text { Seven banks or deposit-taking institutions were liquidated or } \\
\text { taken over. }\end{array}$ & \\
\hline 1998 & One large investment bank failed. & \\
\hline $\begin{array}{l}\text { India } \\
\text { 1993-present }\end{array}$ & $\begin{array}{l}\text { Nonperforming assets reached } 11 \text { percent in 1993-94. } \\
\text { Nonperforming assets of the } 27 \text { public banks estimated at } \\
20 \text { percent in } 1995 \text {. At the end of } 1998 \text { nonperforming loans } \\
\text { estimated at } 16 \text { percent. }\end{array}$ & \\
\hline $\begin{array}{l}\text { Indonesia } \\
1994\end{array}$ & $\begin{array}{l}\text { Nonperforming assets equal to more than } 14 \text { percent of banking } \\
\text { system assets, with more than } 70 \text { percent in state banks. }\end{array}$ & $\begin{array}{l}\text { Recapitalization costs for } \\
\text { five state banks amounted to } \\
\text { nearly } 2 \text { percent of GDP. }\end{array}$ \\
\hline $\begin{array}{l}\text { Lao People's Dem. I } \\
\text { Early 1990s }\end{array}$ & $\begin{array}{l}\text { Rep. } \\
\text { Some banks experienced problems. }\end{array}$ & $\begin{array}{l}\text { Recapitalization of state-owned } \\
\text { commercial banks amounted to } \\
1.5 \text { percent of GDP. }\end{array}$ \\
\hline $\begin{array}{l}\text { Malaysia } \\
\text { 1985-88 }\end{array}$ & $\begin{array}{l}\text { Insolvent institutions accounted for } 3 \text { percent of financial system } \\
\text { deposits; marginally capitalized and possibly insolvent } \\
\text { institutions accounted for another } 4 \text { percent. }\end{array}$ & $\begin{array}{l}\text { Reported losses equivalent } \\
\text { to } 5 \text { percent of GNP. }\end{array}$ \\
\hline $\begin{array}{l}\text { Myanmar } \\
1996-?\end{array}$ & $\begin{array}{l}\text { The largest state-owned commercial bank reported to have large } \\
\text { nonperforming loans. }\end{array}$ & \\
\hline
\end{tabular}




\section{Borderline and Smaller (Nonsystemic) Banking Crises}

\begin{tabular}{|c|c|c|}
\hline $\begin{array}{l}\text { East and Sout } \\
\text { Economy }\end{array}$ & $\begin{array}{l}\text { h Asia-continued } \\
\text { Scope of crisis }\end{array}$ & Estimated losses or costs \\
\hline $\begin{array}{l}\text { Papua New Guinea } \\
1989-?\end{array}$ & $\begin{array}{l}\text { Some } 85 \text { percent of savings and loan associations have ceased } \\
\text { operations. }\end{array}$ & \\
\hline $\begin{array}{l}\text { Singapore } \\
1982\end{array}$ & $\begin{array}{l}\text { Commercial banks' nonperforming loans rose to about } \\
\$ 200 \text { million, or } 0.6 \text { percent of GDP. }\end{array}$ & \\
\hline
\end{tabular}

Taiwan, China

1983-84

Four trust companies and eleven cooperatives failed.

1995

Failure of credit cooperative Changua Fourth in late July sparked runs on other credit unions in central and southern Taiwan.

\begin{tabular}{|c|c|}
\hline \multicolumn{2}{|c|}{ Latin America and the Caribbean } \\
\hline $\begin{array}{l}\text { Costa Rica } \\
\text { 1994-? }\end{array}$ & $\begin{array}{l}\text { One large state-owned commercial bank was closed in } \\
\text { December 1994. The ratio of overdue loans (net of provisions) to } \\
\text { net worth in state commercial banks exceeded } 100 \text { percent in } \\
\text { June } 1995 .\end{array}$ \\
\hline $\begin{array}{l}\text { Guatemala } \\
1990 \text { s }\end{array}$ & $\begin{array}{l}\text { Two small state-owned banks had high nonperforming assets; } \\
\text { these banks discontinued operations in the early } 1990 \text { s. }\end{array}$ \\
\hline $\begin{array}{l}\text { Trinidad and To } \\
\text { 1982-93 }\end{array}$ & $\begin{array}{l}\text { In the early } 1980 \text { s several financial institutions experienced } \\
\text { solvency problems, resulting in the merging of three government- } \\
\text { owned banks in } 1993 \text {. }\end{array}$ \\
\hline $\begin{array}{l}\text { Venezuela, RB } \\
\text { Late } 1970 \text { s and } \\
\text { 1980s }\end{array}$ & $\begin{array}{l}\text { Notable bank failures included Banco Nacional de Descuento } \\
\text { (1978), BANDAGRO (1981), Banco de los Trabajadores de } \\
\text { Venezuela (1982), Banco de Comercio (1985), BHCU (1985), } \\
\text { BHCO (1985), and Banco Lara (1986). }\end{array}$ \\
\hline $\begin{array}{l}\text { Middle Eas } \\
\text { Economy }\end{array}$ & $\begin{array}{l}\text { 1d North Africa } \\
\text { Scope of crisis }\end{array}$ \\
\hline $\begin{array}{l}\text { Egypt, Rep. of } \\
\text { 1991-95 }\end{array}$ & Four public banks were given capital assistance. \\
\hline
\end{tabular}




\section{Borderline and Smaller (Nonsystemic) Banking Crises}

\begin{tabular}{ll}
$\begin{array}{l}\text { Middle East and North Africa-continued } \\
\text { Economy }\end{array}$ & Estimated losses or costs \\
\hline $\begin{array}{l}\text { Jordan } \\
\text { Scope of crisis }\end{array}$ & $\begin{array}{l}\text { The central bank provided } \\
\text { overdrafts equivalent to } \\
10 \text { percent of GDP to meet } \\
\text { a run on deposits and allow } \\
\text { banks to settle foreign } \\
\text { obligations. }\end{array}$ \\
\end{tabular}

\begin{tabular}{|c|c|c|}
\hline \multicolumn{3}{|c|}{ Europe and Central Asia } \\
\hline Economy & Scope of crisis & Estimated losses or costs \\
\hline \multicolumn{3}{|l|}{ Turkey } \\
\hline 1994 & Three banks failed in April 1994. & $\begin{array}{l}\text { Through June } 1994 \text { the } \\
\text { authorities spent } 1 \text { percent } \\
\text { of GDP. }\end{array}$ \\
\hline
\end{tabular}

\section{Transition economies}

\begin{tabular}{lll} 
Economy & Scope of crisis & Estimated losses or costs \\
\hline $\begin{array}{l}\text { Belarus } \\
1995-?\end{array}$ & $\begin{array}{l}\text { Many banks undercapitalized; forced mergers burdened some } \\
\text { banks with poor loan portfolios. }\end{array}$ & \\
\hline $\begin{array}{ll}\text { Estonia } \\
1998\end{array}$ & $\begin{array}{l}\text { Three banks failed in 1998: Maapank (Agricultural Bank), which } \\
\text { accounted for 3 percent of banking system assets, and two } \\
\text { smaller banks, EVEA and ERA. }\end{array}$ & $\begin{array}{l}\text { Maapank's losses reached } \\
\text { (n) }\end{array}$ \\
\hline
\end{tabular}

Tajikistan

1996-?

One of the largest banks is insolvent, one small bank has been

closed, and another (out of 17) is in the process of liquidation.

\begin{tabular}{lll}
$\begin{array}{l}\text { Industrial countries } \\
\text { Economy }\end{array}$ & Scope of crisis & Estimated losses or costs \\
\hline $\begin{array}{l}\text { Australia } \\
1989-92\end{array}$ & $\begin{array}{l}\text { Two large banks received capital from the government to cover } \\
\text { losses. Nonperforming loans rose to 6 percent of assets in } \\
1991-92 .\end{array}$ & $\begin{array}{l}\text { Rescuing state-owned banks } \\
\text { was estimated to cost } \\
\text { 2 percent of GDP. }\end{array}$ \\
\hline $\begin{array}{l}\text { Canada } \\
\text { 1983-85 }\end{array}$ & $\begin{array}{l}\text { Fifteen members of the Canadian Deposit Insurance Corporation, } \\
\text { including two banks, failed. }\end{array}$ \\
\hline
\end{tabular}




\section{Borderline and Smaller (Nonsystemic) Banking Crises}

\begin{tabular}{lll}
$\begin{array}{l}\text { Industrial countries-continued } \\
\text { Economy }\end{array}$ & Scope of crisis & Estimated losses or costs \\
\hline $\begin{array}{l}\text { Denmark } \\
1987-92\end{array}$ & $\begin{array}{l}\text { Cumulative loan losses over } 1990-92 \text { were } 9 \text { percent of loans; } \\
40 \text { of the } 60 \text { problem banks were merged. }\end{array}$ \\
\hline France & Credit Lyonnais experienced serious solvency problems. & $\begin{array}{l}\text { According to unofficial } \\
\text { estimates, losses totaled about } \\
\text { \$10 billion, making it the } \\
\text { largest bank failure up to that } \\
\text { time. }\end{array}$ \\
\hline
\end{tabular}

\begin{tabular}{|c|c|c|}
\hline $\begin{array}{l}\text { Germany } \\
\text { Late } 1970 \text { s }\end{array}$ & So-called Giroinstitutions faced problems. & \\
\hline $\begin{array}{l}\text { Greece } \\
1991-95\end{array}$ & $\begin{array}{l}\text { Localized problems required significant injections of public } \\
\text { funds into specialized lending institutions. }\end{array}$ & . \\
\hline $\begin{array}{l}\text { Iceland } \\
1985-86\end{array}$ & $\begin{array}{l}\text { One of three state-owned banks became insolvent and was } \\
\text { eventually privatized in a merger with three private banks. }\end{array}$ & \\
\hline 1993 & $\begin{array}{l}\text { The government was forced to inject capital into one of the } \\
\text { largest state-owned commercial bank after it suffered serious } \\
\text { loan losses. }\end{array}$ & \\
\hline $\begin{array}{l}\text { Italy } \\
1990-95\end{array}$ & $\begin{array}{l}\text { During } 1990-94,58 \text { banks (accounting for } 11 \text { percent of lending) } \\
\text { were merged with other institutions. }\end{array}$ & \\
\hline $\begin{array}{l}\text { New Zealand } \\
1987-90\end{array}$ & $\begin{array}{l}\text { One large state-owned bank accounting for one-quarter of } \\
\text { banking assets experienced serious solvency problems due } \\
\text { to high nonperforming loans. }\end{array}$ & $\begin{array}{l}\text { The bank required a capital } \\
\text { injection equal to } 1 \text { percent of } \\
\text { GDP. }\end{array}$ \\
\hline $\begin{array}{l}\text { United Kingdom } \\
1974-76\end{array}$ & "Secondary Banking Crisis." & \\
\hline 1980 s and 1990 s & $\begin{array}{l}\text { Notable bank failures included Johnson Matthey (1984), } \\
\text { Bank of Credit and Commerce International (1991), and } \\
\text { Barings (1995). }\end{array}$ & \\
\hline $\begin{array}{l}\text { United States } \\
\text { 1984-91 }\end{array}$ & $\begin{array}{l}\text { More than } 1,400 \text { savings and loan institutions and } 1,300 \\
\text { banks failed. }\end{array}$ & $\begin{array}{l}\text { Cleaning up savings and loan } \\
\text { institutions cost } \$ 180 \text { billion, or } \\
3 \text { percent of GDP. }\end{array}$ \\
\hline
\end{tabular}

Source; World Bank data and staff; Sheng 1995; World Bank 1989; Baer and Klingebiel 1995; Vittas 1992; Sundarajan and Balino 1991; Rodriguez 1994; Morris and others 1990; Blass and Grossman 1995; Fleming and Talley 1996; Lindgren, Garcia, and Saal 1996; Fleming, Chu, and Bakker 1996. 


\section{References}

Baer, Herbert, and Daniela Klingebiel. 1995. "Systemic Risk When Depositors Bear Losses: Five Case Studies." In G. G. Kaufman, ed., Research in Financial Services: Private and Public Policy. vol. 7. Greenwich, Conn.: JAI Press.

Blass, Asher A., and Richard S. Grossman. 1995. "A Costly Guarantee? The 1983 Israel Bank Shares Crisis Revisited." Discussion Paper 95.05. Maurice Falk Institute for Economic Research in Israel, Jerusalem.

Caprio, Gerard, and Daniela Klingebiel. 1996. "Bank Insolvencies: Cross-country Experience." Policy Research Working Paper 1620. World Bank, Washington, D.C.

1997. "Bank Insolvency: Bad Luck, Bad Policy, or Bad Banking?" In Michael Bruno and Boris Pleskovic, eds., Annual World Bank Conference on Development Economics 1996. Washington, D.C.: World Bank.

Fleming, Alex, and Samuel Talley. 1996. “The Latvian Banking Crisis: Lessons Learned.” Policy Research Working Paper 1590. World Bank, Washington, D.C.

Fleming, Alex, Lily Chu, and Marie-Renée Bakker. 1996. “The Baltics-Banking Crises Observed.” Policy Research Working Paper 1647. World Bank, Washington, D.C.

Lindgren, Carl-Johan, Gillian Garcia, and Matthew I. Saal. 1996. Bank Soundness and Macroeconomic Policy. Washington, D.C.: International Monetary Fund.

Morris, Felipe, Mark Dorfman, Jose Pedro Ortiz, and Maria Claudio Franco. 1990. Latin America's Banking Systems in the 1980s. World Bank Discussion Paper 81. Washington, D.C.

Rodriguez, Carlos Alfredo. 1994. “Argentina: Fiscal Disequilibria Leading to Hyperinflation.” In William Easterly, Carlos Alfredo Rodriguez, and Klaus Schmidt-Hebbel, eds., Public Sector Deficits and Macroeconomic Performance. New York: Oxford University Press.

Rojas-Suarez, Liliana, and Steven Weisbrod. 1995. "Banking Crises in Latin America: Experiences and Issues.” In Ricardo Hausmann and Liliana Rojas-Suarez, eds., Banking Crises in Latin America. Baltimore, Md.: The Johns Hopkins University Press.

Sheng, Andrew, ed. 1996. Bank Restructuring: Lessons from the 1980s. Washington, D.C.: World Bank.

Sundarajan, Vasudevan, and Tomas Jose T. Balino, eds. 1991. Banking Crises: Structural Weaknesses, Support Operations, and Economic Consequences. Washington, D.C: International Monetary Fund.

Vittas, Dimitri, ed. 1992. Financial Regulation: Changing the Rules of the Game. EDI Development Studies. Washington, D.C.: World Bank Economic Development Institute.

World Bank. 1989. World Development Report 1989: Financial Systems and Development. New York: Oxford University Press. 



\section{Recent World Bank Discussion Papers (continued)}

No. 384 Integrating Social Concerns into Private Sector Decisionmaking: A Review of Corporate Practices in the Mining, Oil, and Gas Sectors. Kathryn McPhail and Aidan Davy

No. 385 Case-by-Case Privatization in the Russian Federation: Lessons from International Experience. Harry G. Broadman, editor

No. 386 Strategic Management for Government Agencies: An Institutional Approach for Developing and Transition Economies. Navin Girishankar and Migara De Silva

No. 387 The Agrarian Economies of Central and Eastern Europe and the Commonwealth of Independent States: Situation and Perspectives, 1997. Csaba Csaki and John Nash

No. 388 China: A Strategy for International Assistance to Accelerate Renewable Energy Development. Robert P. Taylor and V. Susan Bogach

No. 389 World Bank HIV/AIDS Interventions: Ex-ante and Ex-post Evaluation. Julia Dayton

No. 390 Evolution of Agricultural Services in Sub-Saharan Africa: Trends and Prospects. V. Venkatesan and Jacob Kampen

No. 391 Financial Incentives for Renewable Energy Development: Proceedings of an International Workshop, February 17-21. 1997, Amsterdam, Netherlands. E. Scott Piscitello and V. Susan Bogach

No. 392 Choices in Financing Health Care and Old Age Security: Proceedings of a Conference Sponsored by the Institute of Policy Studies, Singapore, and the World Bank, November 8, 1997. Nicholas Prescott, editor

No. 393 Energy in Europe and Central Asia: A Sector Strategy for the World Bank Group. Laszlo Lovei

No. 394 Kyrgyz Republic: Strategy for Rural Growth and Poverty Alleviation. Mohinder S. Mudahar

No. 395 School Enrollment Decline in Sub-Saharan Africa: Beyond the Supply Constraint. Joseph Bredie and Girindre Beeharry

No. 396 Transforming Agricultural Research Systems in Transition Economies: The Case of Russia. Mohinder S. Mudahar, Robert W. Jolly, and Jitendra P. Srivastava

No. 398 Land Reform and Farm Restructuring in Moldova: Progress and Prospects. Zvi Lerman, Csaba Csaki, and Victor Moroz

No. 400 Russian Enterprise Reform: Policies to Further the Transition. Harry G. Broadman, editor

No. 401 Russian Trade Policy Reform for WTO Accession. Harry G. Broadman, editor

No. 402 Trade, Global Policy, and the Environment. Per G. Gredriksson, editor

No. 403 Ghana: Gender Analysis and Policymaking for Development. Shiyan Chao, editor

No. 404 Health Care in Uganda: Selected Issues. Paul Hutchinson, in collaboration with Demissie Habte and Mary Mulusa

No. 405 Gender-Related Legal Reform and Access to Economic Resources in Eastern Africa, Gita Gopal

No. 406 The Private Sector and Power Generation in China. Energy and Mining Sector Unit, East Asia and Pacific Region, World Bank

No. 407 Economic Growth with Equity: Ukrainian Perspectives. John Hansen, editor

No. 408 Economic Growth with Equity: Which Strategy for Ukraine? John Hansen and Diana Cook

No. 409 East Asian Corporations: Heroes or Villains? Stijn Claessens, Simeon Djankov, and Larry H. P. Lang

No. 411 Making the Transition Work for Women in Europe and Central Asia. Marnia Lazreg, editor

No. 412 Intellectual Property Rights and Economic Development. Carlos A. Primo Braga, Carsten Fink, and Claudia Paz Sepulveda

No. 413 Management and Resolution of Banking Crises: Lessons from the Republic of Korea and Mexico. Jose De Luna-Martinez

No. 414 Liquefied Natural Gas in China: Options for Markets, Institutions, and Finance. Dean Girdis, Stratos Tavoulareas, and Ray Tomkins

No. 416 Fostering Competition in China's Power Markets. Noureddine Berrah, Ranjit Lamech, and Jianping Zhao

No. 417 Hungary: Modernizing the Subnational Government System. Mihaly Kopanyi, Samir El Daher, Deborah Wetzel, Michel Noel, and Anita Papp

No. 419 Measuring and Apportioning Rents from Hydroelectric Power Developments. Mitchell Rothman

No. 420 Financing of Private Hydropower Projects. Chris Head

No. 421 Free Trade Area Membership as a Stepping Stone to Development: The Case of ASEAN. Emiko Fukase and Will Martin

No. 422 Environmental Health: Bridging the Gaps. James A. Listorti and Fadi M. Doumani 


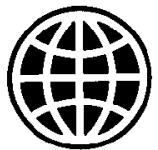

THE WORLDBAN

1818 H Street. N.W.

Washington, D.C. 20433 USA

Telephone: 202-477-1234

Facsimile: 202-477-6391

Internct: www.worldbank.org

E-mail: feedback@worldbank.org

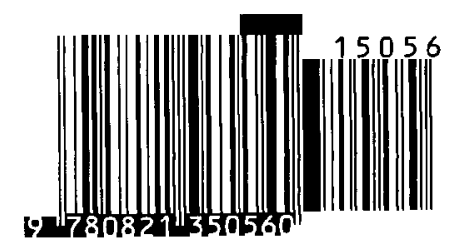

ISBN 0-8213-5056-0 